\title{
54. TECTONIC PROCESSES AND THE HISTORY OF THE MARIANA ARC: A SYNTHESIS OF THE RESULTS OF DEEP SEA DRILLING PROJECT LEG $60^{1}$
}

\author{
Donald M. Hussong, Hawaii Institute of Geophysics, University of Hawaii, Honolulu, Hawaii \\ and \\ Seiya Uyeda, Earthquake Research Institute, University of Tokyo, Bunkyo-ku, Tokyo 113, Japan
}

\begin{abstract}
DSDP Leg 60 drilled 10 sites on an east-west transect at $18^{\circ} \mathrm{N}$ across the tectonically active trench, volcanic arc, and extensional back-arc basin on the Mariana arc system. The analysis of these cores, augmented by considerable geological and geophysical information collected in preparation for the drilling, comprises the most complete data set presently available in a zone of convergence of two ocean lithospheric plates.

No significant accretion of Pacific plate sediment or crustal rocks is found on the overriding Mariana arc (Philippine plate). The arc igneous basement, which has now been sampled from the trench slope break to within a few tens of kilometers from the volcanic arc, is of early Oligocene or Eocene age and is geochemically identified as being of arc origin. Apparently exclusively tensional deformation (expressed as high-angle faulting) and vertical movement producing net subsidence occur on both sides of the trench and increase with proximity to the trench axis. Only sparse sediments are observed in the trench, on the inner trench wall, and on much of the eastern part of the fore-arc. Collectively, these features suggest that, although some periods of accretion may have occurred in the past, the Mariana fore-arc at $18^{\circ} \mathrm{N}$ is subject to overall tectonic erosion by the subducting plate.

Arc volcanism has probably been continuous since the Eocene, but initial back-arc basin rifting has occurred at or near the arc volcanoes, producing drastic subsidence and subsequent eruption in deep water with limited lateral transport of volcanic material. Apparent fore-arc volcanoes occur close to the trench axis where the subducting ocean plate is only 15 to $30 \mathrm{~km}$ deep. If these features are volcanic and autochthonous, their magma source must be either from deeper in the subduction zone (requiring considerable lateral transport of the magma) or in the oceanic plate-or they must be older features that were once above a much deeper subducting slab.

Back-arc spreading in the Mariana Trough at $18^{\circ} \mathrm{N}$ apparently began with rifting somewhat east of the axis of arc volcanism in the latest Miocene, is approximately symmetric, and has continued at a half-rate of less than $2.15 \mathrm{~cm} / \mathrm{y}$. to present. The present Mariana arc volcanoes are thus built over thin crust that is physiographically part of the back arc basin and is either stretched, thinned, and subsided arc crust or was generated at the back-arc spreading center. Backarc spreading has ridge/transform/ridge geometry, earthquake distribution, crustal structure, geomorphology, and MORB-type rocks that all mimic-yet are subtly and consistently different from-mature, large, deep ocean spreading centers. The Mariana Trough may, however, be similar to other less well-known regions where the relatively thick island arc or continental crust is initially rifting.

The results of IPOD active margin drilling off Japan, the Marianas, Mexico, and Guatemala suggest that there may be systematic relationships between subduction and plate motion geometry, back-arc spreading, magma types, vertical tectonics, and the occurrence of fore-arc accretion versus tectonic erosion.
\end{abstract}

\section{INTRODUCTION}

Planning for DSDP Leg 60 began in 1974, when an east-west transect across the Philippine Sea at $18^{\circ} \mathrm{N}$ latitude (Fig. 1) was selected for concentrated research leading to scientific drilling. The western portion of the transect, crossing the tectonically inactive West Philippine Basin, Palau-Kyushu Ridge, Parece Vela Basin, and West Mariana Ridge, was drilled during DSDP Leg 59 (Kroenke, Scott, et al., 1980). The tectonically active part of the Mariana arc system is in the eastern portion of the transect, and includes the extensional Mariana Trough back-arc basin, the Mariana volcanic arc, and the lithospheric plate subduction zone marked by the Mariana Trench (Fig. 2). This wide region of tectonic activity, the product of processes associated with convergence of two purely oceanic plates (Philippine and Pacific), was drilled during Leg 60.

\footnotetext{
${ }^{1}$ Initial Reports of the Deep Sea Drilling Project, Volume 60.
}

By the planning stage of Legs 59 and 60 , the broad structural history of the Mariana arc system had already been outlined by Karig (1971). He incorporated the results of DSDP Leg 6 (Fischer, Heezen, et al., 1971) with marine geophysical profiling and geological sampling and with the known geology of the Mariana Islands (primarily Tracey et al., 1964) to produce an evolutionary model for the Philippine Sea that has proven essentially correct. Karig suggested that the active volcanic chains that form above and essentially parallel to subduction zones sometimes split longitudinally. This rifting develops into extensional basins where new seafloor crust is generated. As these back-arc basins enlarge, the inactive, remnant parts of the original volcanic arc move away from the still-active volcanic arc above the subduction zone. In the Mariana system, this sequence of events has occurred at least twice. First, according to Karig (1971), an original volcanic arc, which probably originated in the Eocene, split in the late Oligocene or early Miocene and left a remnant arc (the Palau-Kyushu Ridge) behind an extensional back-arc basin (the Parece 
D. M. HUSSONG, S. UYEDA

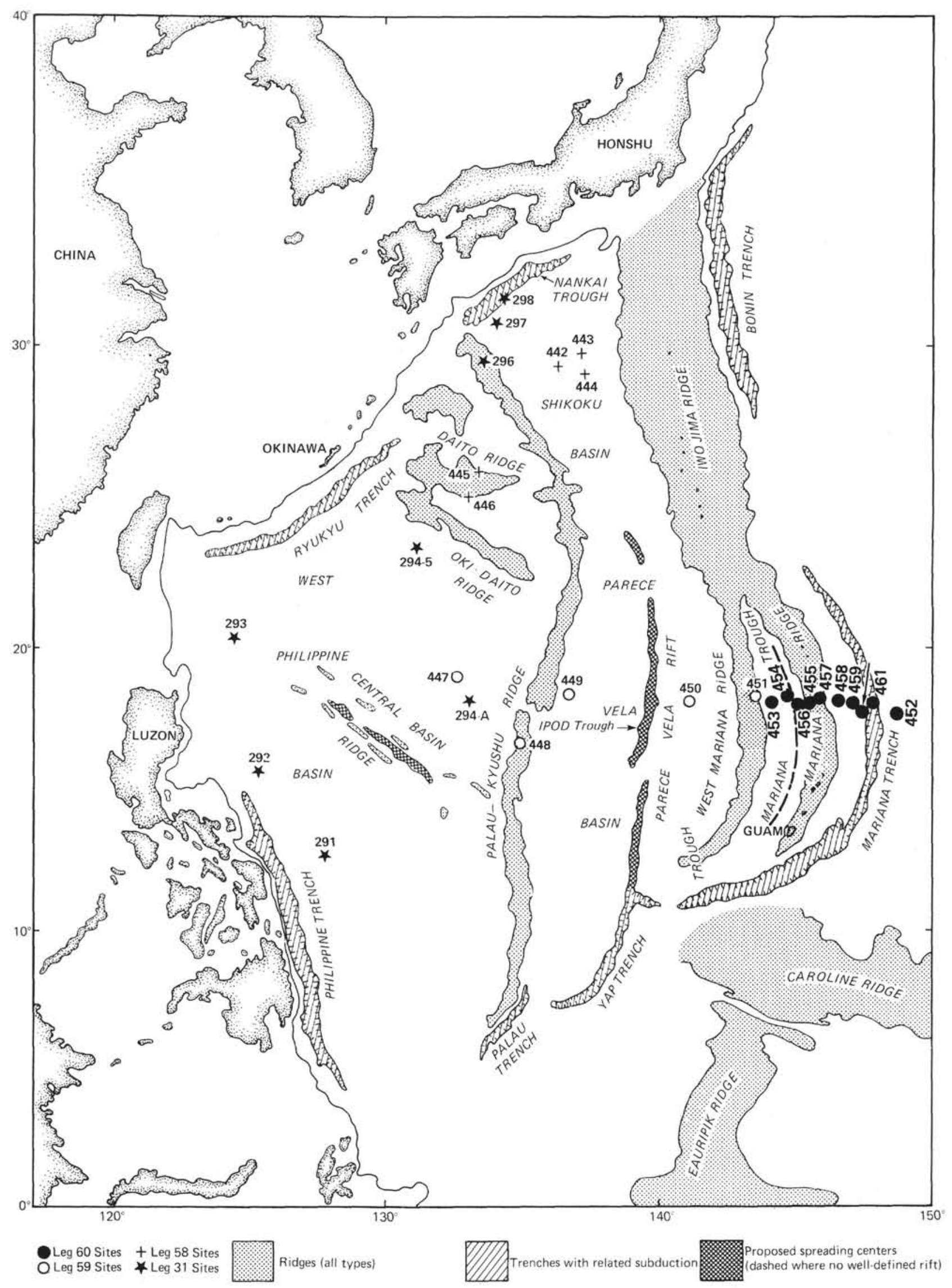

Figure 1. Location of DSDP Sites in the Philippine Sea, Legs 31, 58, 59, and 60. 


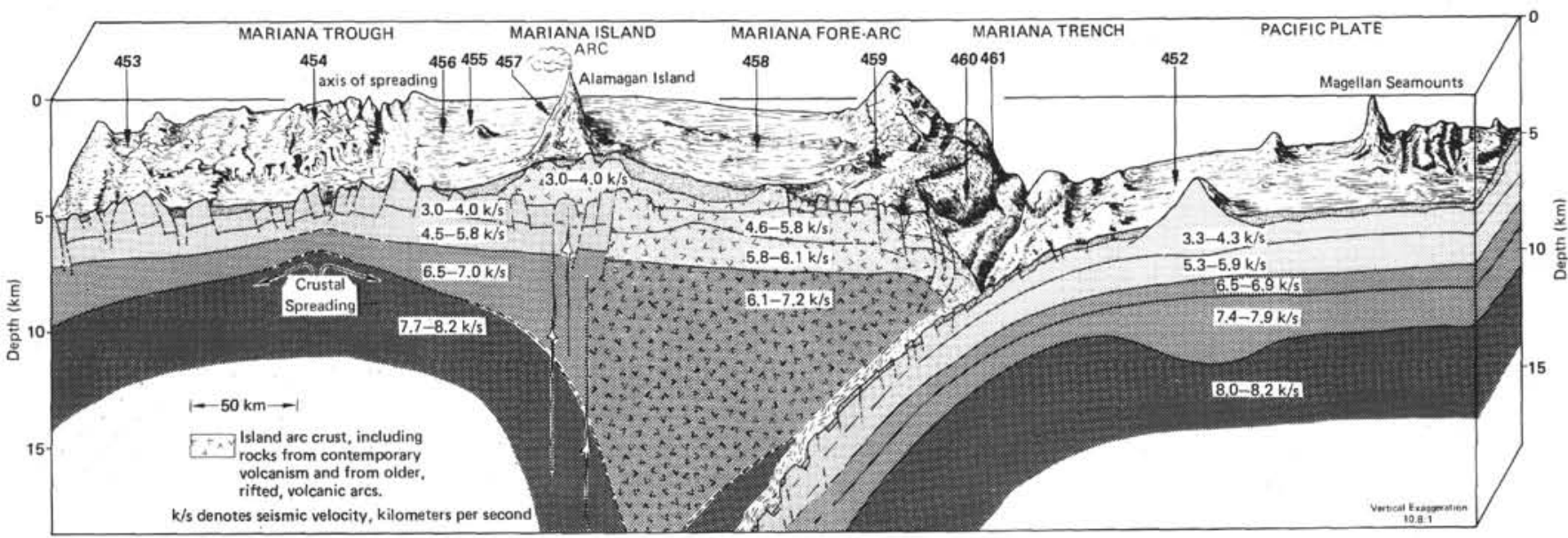

Figure 2. Generalized structure of the portion of the active Mariana Arc system drilled during Leg 60, from Hussong (this volume).

Vela Basin) that opened through most of the rest of the Miocene. After a subsequent period of no evident rifting, the active volcanic arc rifted a second time (in the late Pliocene, according to Karig, 1971), and another back-arc basin (the Mariana Trough) was formed. Volcanism stopped on the remnant West Mariana Ridge as it was being separated from the still-active Mariana Island arc by the Mariana Trough. This latest phase of back-arc spreading is still in progress.

Researchers have not agreed on a general model for the origin of the West Philippine Basin. Uyeda and BenAvraham (1972) proposed that the Basin is a portion of old oceanic crust that formed on the Kula-Pacific spreading center. They suggest that its eastern boundary (the present location of the Palau-Kyushu Ridge) was a Cretaceous ridge-ridge transform fault (Fig. 3A, B). According to them, when the direction of motion of the Pacific plate changed in the Eocene $(\sim 40 \mathrm{Ma})$, it caused convergence along its western boundary, with subsequent subduction of the plate along the zone of weakness at the old Kula-Pacific transform (Fig. 3C). Spreading in the trapped West Philippine Basin stopped. With the establishment of Pacific plate subduction, the Eocene-to-present evolutionary history (Karig, 1971) produced the ridges and basins in Figure 3D.

In contrast to the Uyeda and Ben-Avraham (1972) model, Karig (1971) suggested that the West Philippine Basin formed from back-arc spreading. Later (1975), he outlined a plate reconstruction according to which the basin opened in a northeast-southwest direction behind the Oki-Daito Ridge and southern Palau-Kyushu Ridge prior to $36 \mathrm{Ma}$. In response to initiation of subduction along all its boundaries, the entire early Philippine plate system then rotated to its present east-west opening orientation.

DSDP Legs 31 (Karig, Ingle, et al., 1975), 58 (Klein, Kobayashi, et al., 1980), and 59 (Kroenke, Scott, et al., 1980) failed to produce data that could determine whether the West Philippine Basin formed in a large ocean basin or in a back-arc environment. Nor were they able to obtain crustal age data that would permit selection of a correct age distribution model in the basin from among the somewhat conflicting analyses by Lee and Hilde (1971), Ben-Avraham et al. (1972), Karig et al. (1973), Louden (1976), Watts et al. (1977), and Shih (1980).

Considering the lack of definitive data, we initially favored the trapped oceanic crust model as the origin of the West Philippine Basin because it is less complex than the model involving large-scale plate rotation. Paleomagnetic data indicate, however, that Guam has undergone about $50^{\circ}$ of clockwise rotation since the Miocene (Larson et al., 1975) and $80^{\circ}-90^{\circ}$ of rotation since the Eocene (personal communication, B. Keating, 1981), which may be evidence for the plate rotation inherent in Karig's (1975) model. Until the origin of the West Philippine Basin is better understood, however, our own discussion of Leg 60 results will adhere to the framework of a better understood portion of the regional plate tectonic history, beginning with the Eocene volcanism on the Palau-Kyushu Ridge.

Leg 59 drilling at Sites 448 (Palau-Kyushu Ridge), 449 (western Parece Vela Basin), 450 (eastern Parece Vela Basin), and 451 (West Mariana Ridge) successfully verified Karig's (1975) evolutionary model for these features, with slight adjustments in the timing of events.

\begin{tabular}{lcc}
\hline & $\begin{array}{c}\text { Ma } \\
\text { (Karig, 1975) }\end{array}$ & $\begin{array}{c}\text { Ma } \\
\text { (Scott et al., 1980) }\end{array}$ \\
\hline $\begin{array}{c}\text { Palau-Kyushu Ridge } \\
\text { volcanism }\end{array}$ & $\begin{array}{c}\text { early Tertiary } \\
(?)-25\end{array}$ & $42(?)-29$ \\
$\begin{array}{c}\text { Parece Vela Basin } \\
\text { opening }\end{array}$ & $25-18$ & $30-18(-14)$ \\
$\begin{array}{c}\text { West Mariana Ridge } \\
\text { volcanism }\end{array}$ & $?-5$ & $29-9$ \\
\hline
\end{tabular}

Karig (1975) noted that back-arc spreading seems to correspond to periods of abundant volcanism and thus may be related to pulses of increased tectonic activity related in turn to increases in rate of subduction. Given the chronology of tectonic events in the Philippine Sea, as modified by Leg 59 drilling results, Scott et al. (1980) suggest that periods of back-arc spreading occurred dur- 

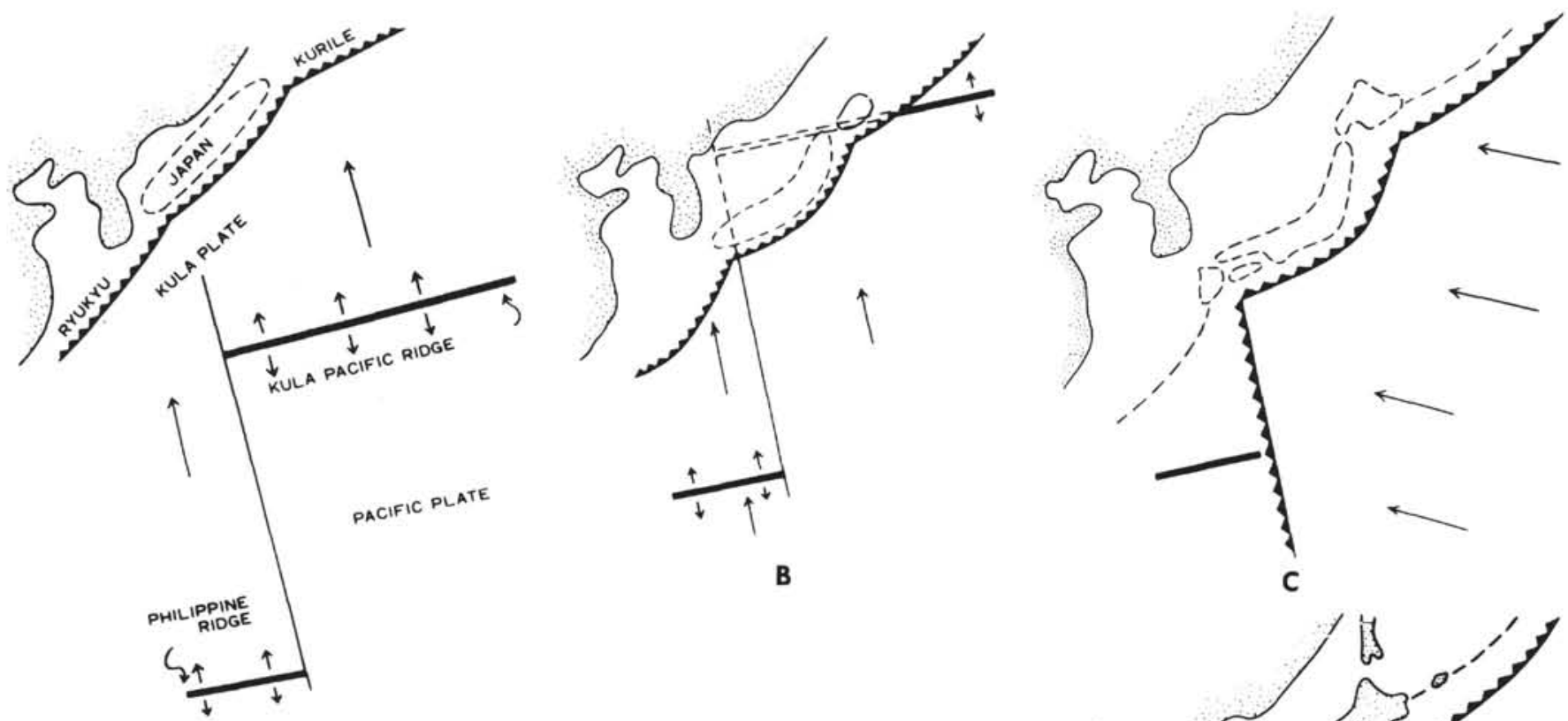

A

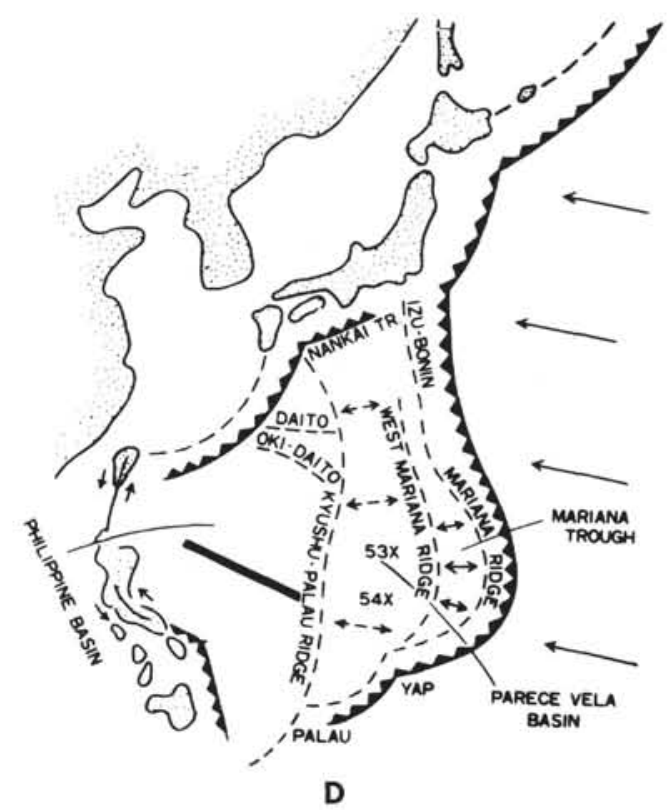

Figure 3. Reconstruction of major plate motion in the western Pacific since the Cretaceous (from Uyeda and Ben-Avraham, 1972). This model depicts the West Philippine basin as deep ocean crust forming in the Cretaceous at a segment of the Kula-Pacific spreading center. By the Late Cretaceous the northern spreading ridge was subducted beneath Japan (B). In the late Eocene the motion of the Pacific plate shifted from northerly to northwest, causing the initiation of subduction at the zone of weakness along the transform fault on the western margin (C). The PalauKyushu volcanic arc formed above this subduction zone. From the Eocene to now, the present system of back-arc basins and remnant arcs developed according to the scheme of Karig (1971).

ing the absence, or near absence, of arc volcanism (and that levels of volcanic activity are high when there is no back-arc spreading). Scott et al. (1980) further suggest that this nonconcurrence of arc volcanism and back-arc spreading is related to the geometry of subduction. These observations will be discussed later in light of data collected during Leg 60 .

\section{RESULTS OF LEG 60 AND RELATED SITE SELECTION CRUISES}

Details of the results of Leg 60 and of the extensive marine geological and geophysical data collection conducted during site selection surveys prior to drilling are contained in the appropriate site and descriptive chapters in this volume. This synthesis chapter will sum- marize those aspects of the work that relate directly to tectonics. Rather than discuss our results in chronological order of drilling, we will describe them from east to west along the $18^{\circ} \mathrm{N}$ transect.

\section{Pacific Plate (Site 452)}

Site selection studies of the Pacific plate east of the Mariana Trench were designed to determine its age, general morphology, and crustal structure. Our subsequent drilling sought to obtain a section of sediment and upper crustal rocks that could serve as a reference of material delivered to the trench.

Site 452 is on the Pacific plate (Fig. 1) about $75 \mathrm{~km}$ east of the Mariana Trench axis (Fig. 2; Plates 1 and 2, Hussong, back pocket, this volume) in 5860 meters of 
water. The site is surrounded by seamounts of the Magellan group but was purposely located on featureless seafloor well away from these seamounts.

Pacific-wide magnetic anomaly compilations such as the one by Hilde et al. (1977) show the region around Site 452 to be part of the Mesozoic quiet zone. An apparent magnetic anomaly stripe, however, was found by Hussong (this volume) during the drill site surveys. Although the anomalies have not been identified, their orientation suggests that they may be part of the Mesozoic sequence identified by Hilde et al. (1976) as the Japanese sequence.

The seismic velocity structure near Site 452 was determined by LaTraille and Hussong (1980), who found an average of $6.8 \mathrm{~km}$ of crust beneath $5.5 \mathrm{~km}$ of water, which is similar to the average thickness of younger oceanic crust in the Pacific basin. They found, however, that the deeper Layers 2 and 3 are thinner than Pacific averages, whereas Layer $2 \mathrm{~A}$ is unusually thick, perhaps as a result of midplate volcanism (the age and origin of the Magellan Seamounts is unknown) or the presence of very thick chert layers.

The drilling results in the two holes at Site 452 were disappointing. The occurrence of impenetrable cherts of probable Campanian age prevented drilling after less than 50 meters of Neogene sediment was cored. As pointed out in the site chapter (this volume), however, 452 is one of 16 DSDP sites in the far western Pacific that has a Cretaceous-Neogene disconformity. Thus, because there is virtually no Paleogene sediment on the deep seafloor in the western Pacific, it can be argued that any Paleogene sediment on the island arc side of the Mariana Trench is probably not derived from the deep sea portion of the subducting ocean plate.

\section{Mariana Trench (Sites 460 and 461)}

Prior to Leg 60 , there existed little data to apply to the basic question of whether the island arc wall of the Mariana Trench is composed of an accreted prism of oceanic plate and trench axis sediments and rocks (as described by Karig, 1974; Karig and Sharman, 1975) uplifted by imbricate thrusting (Seely et al., 1974) or whether it is arc material exposed by tectonic erosion of the overriding Philippine plate by the subducting Pacific plate. Sites 460 and 461 were drilled in order to test the composition of the inner trench wall.

In the Leg 60 area (Fig. 2) the Mariana Trench is often over 8600 meters deep. The inner (island arc) wall of the Trench rises, with slopes as great as $9^{\circ}$, to the trench slope break at about 4100 meters. West of the trench slope break the seafloor rises slowly toward the volcanic arc. The site surveys located no ponded sediments in the trench axis between $17^{\circ} 15^{\prime} \mathrm{N}$ and $18^{\circ} 15^{\prime} \mathrm{N}$ latitude and were unable to identify any significant sediment accumulation on the adjoining inner trench wall (Hussong and Fryer, this volume). The first clearly defined sediments were not observed until west of the trench slope break. Mrozowski et al. (this volume) do note a few terraces deep on the wall that might be the seafloor expression of wedges of sediment in a tiny accreted prism, but these features are poorly defined and remain unsampled.
Piston coring on the inner wall yielded clay and volcanic ash with Recent microfossils and fragments of serpentinite (Hussong and Fryer, this volume). In 1976 the Dmitry Mendeleev dredged a wide assortment of igneous and metamorphic rocks from this part of the trench wall, including basalts, gabbros, andesites, and ultramafic serpentinites (e.g., Beccaluva et al., 1980).

DSDP Sites 460 and 461 , with two holes at each site, were drilled on the inner trench wall. At Site 460 , an 85-meter section revealed Pleistocene oozes overlying a 47-meter sequence of calcareous Eocene and Oligocene sediments. Although only a short section with incomplete core recovery, the Eocene-Oligocene sediments apparently represent a continuous and relatively undisturbed sequence that has subsided to the present depth of $\sim 6500$ meters after deposition above the carbonate compensation depth. A second hole at this site, Hole $460 \mathrm{~A}$, retrieved reworked and mixed sediments containing microfossils of all ages from Quaternary through Eocene.

Site 461 , at a water depth of over $7 \mathrm{~km}$, is the deepest site ever drilled in the ocean. Unfortunately, penetration in the two holes at this site was very slight. Recovered were apparent olistostrome deposits of redeposited and mixed Cenozoic and Mesozoic sediments, as well as cobbles of igneous and metamorphic rocks. The Mesozoic fossils were apparently redeposited from nearby outcrops and include Late Cretaceous radiolarians in Holes $460 \mathrm{~A}$ and 461 and Upper Jurassic calpionellids in Hole 460 (Azéma and Blanchet, this volume).

At both Sites 460 and 461 , a polymict assortment of basalt, metabasalt, bronzite-andesite, and gabbro cobbles and fragments were cored. All these rocks seem to be debris mixed with sediment and may not represent basement material. Chemically, the rocks that were analyzed all have island arc, as opposed to ocean crust, affinities (Wood et al., this volume).

\section{Mariana Arc and Fore-arc}

Geophysical surveys on the Mariana fore-arc near $18^{\circ} \mathrm{N}$ show two structural provinces: an eastern region characterized by thin sediments disturbed by many normal faults and a western province with thick stratified sediments that deepen toward the volcanic arc (Mrozowski and Hayes, 1980). These sediments overlie an apparent volcanic basement with velocities of 3.0-5.8 $\mathrm{km} / \mathrm{s}$ (LaTraille and Hussong, 1980). A deeper layer with seismic velocities of $6.1-6.5 \mathrm{~km} / \mathrm{s}$ at sub-bottom depths of 4 to $5 \mathrm{~km}$ was also reported by LaTraille and Hussong (1980). They suggest that this deeper layer may be the original back-arc basin or oceanic crust on which the arc volcanic rocks erupted. Occasional short-wavelength, high-amplitude gravity anomalies, such as identified but not interpreted by Sager (1980), are often associated with magnetic dipoles and may be large igneous bodies that are wholly or partially buried by the fore-arc sediments (Hussong and Fryer, this volume).

Based on the site surveys, Hussong and Fryer (this volume) found no thrusting, folding, or other obviously compressional structures on the fore-arc. In fact, they and Mrozowski and Hayes (1980) found only tensional features (high-angle offsets interpreted as normal faults) 
throughout the region. Mrozowski and Hayes (1980) found that faults strike generally parallel to the arc, have offsets ranging from 10 to $200-300$ meters, extend in many places through the sediments and into the basement, and are predominantly down-dropped to the east near the trench. Thus, as noted by Hussong and Fryer (this volume), except for the megashear zone at the contact between the Pacific and Philippine plates, the top of the crust throughout this region of plate convergence is, paradoxically, in tension.

Large seamounts were also observed on the outer edge of the fore-arc, occasionally forming part of, or occurring just west of, the trench-slope break. As noted by Hussong and Fryer (this volume), these seamounts, which sometimes exhibit gravity and magnetic anomalies suggesting igneous origin, are too close to the trench axis to fit our simple models of volcanogenesis above subduction zones. Projecting the Benioff Zone determination of Katsumata and Sykes (1969), the top of the subducting slab is less than $30 \mathrm{~km}$ deep beneath these fore-arc seamounts.

Two sites (458 and 459$)$ were drilled on the fore-arc, and a third (457) was drilled on the volcanic axis of the arc (Fig. 2). Site 457, on the slope of Alamagan Island, was of little value because it did not penetrate the $\mathrm{Re}$ cent coarse pyroclastic sand that blankets the region.

Site 458 was drilled where site surveys had delineated a local 40-mgal gravity high with little bathymetric expression but with a large associated magnetic anomaly about $80 \mathrm{~km}$ west of the trench axis (Fig. 2). Site 459 was drilled just west of the trench slope break, about 45 $\mathrm{km}$ west of the trench. At both sites, thick sediments and substantial sections of igneous basement were penetrated (see site chapters). The basal sediments at both fore-arc sites are coarse, highly altered volcaniclastic debris deposited on island-arc-related volcanic basement in the early Oligocene at Site 458 and in the Eocene at Site 459 (Fig. 4). From then until the middle Miocene, nannofossil chalks were being formed at Site 458 , and thick turbidites accumulated at Site 459 . At this same time, a sequence of calcareous and vitric mud (similar to the Site 458 sequence) was being deposited at Site 460 , after which that trench wall site subsided to its present depth of about 6500 meters. The sedimentary sequences at Sites 458 and 459 have several hiatuses that are generally independent of each other, except for a prominent hiatus from late Miocene to Pliocene (Fig. 4). The fore-arc sites show an increase in biogenic sedimentation in the Pleistocene that, by Recent time, became primarily siliceous ooze.

The sedimentary history of the fore-arc sites is strongly influenced by tectonic events. Considering both the paleomagnetic results of Bleil (this volume) and the character of the sediments, the Oligocene-Miocene chalks at Site 458 appear to have been deposited near the equator. Since there are no turbidites at Site 458, the dominant chalk deposits in the hole may have formed on a local bathymetric high, or even on an uplifted part of the fore-arc. In contrast, the thick turbidites at Site 459 indicate that this part of the fore-arc was subject to subsidence relative to its surroundings (or to uplift of the surrounding area), particularly during the early Oligocene and Miocene. At both sites, local sediment reworking and redeposition occurred at all times, even during the relatively quiescent chalk deposition at Site 458. This reworking may be an effect of the extensive faulting observed in the seismic reflection profiles in the area.

The deeper, more consolidated sediments at Site 459 (and to a lesser extent at Site 458) were highly fractured and faulted. The dominant small-scale normal faulting observed in the cores supports the conclusion, based on surface geophysical observations, that the fore-arc is under tension. Unfortunately, the small-scale deformation of the sediments in the Leg 60 cores, which clearly might be related to the tectonics of the fore-arc, has yet to be studied in detail.

Figure 4 shows that volcanic products (ash layers and glass or claystone derived from altered volcanic glass) occur throughout the fore-arc sediments but are abundant from the late Eocene through the early Oligocene $(>42-32 \mathrm{Ma})$, early to middle Miocene $(20-13 \mathrm{Ma})$, and late Miocene to Recent $(8-0 \mathrm{Ma})$. There is a more detailed discussion of this figure in a later section on Mariana Arc volcanism.

Penetration into fore-arc basement, which had not been accomplished on any other DSDP leg, was very successful on Leg 60 . In Hole 458 we penetrated 209 meters and in Hole 459B 132.5 meters into igneous basement. The upper 130 meters of igneous basement at Site 458 consists of bronzite and clinopyroxene-bearing, nearly plagioclase-free lavas which resemble the highmagnesian-andesites associated wịth boninites, an unusual rock type found in some island arcs (Meijer et al., this volume). Deeper in Hole 458 these distinctive andesites are interbedded with basalts, which Wood et al. (this volume) show to be chemically similar to the tholeiitic basalts that dominate the Site 459 basement and are typically of island arcs.

The nearly 130 meters of igneous basement cored at Site 459 consists of vesicular, clinopyroxene-plagioclase, tholeiitic basalts in pillow lavas, flows, and possible sills. The rocks show a range of iron enrichment $\left(\mathrm{Fe}_{2} \mathrm{O}_{3}\right.$ at $\left.9.8-13.6 \%\right)$, indicating that they are highly fractionated at typical values for island arc tholeiites (Wood et al., this volume).

The igneous rocks at Sites 458 and 459 are highly fractured and altered to smectite-phillipsite assemblages. Natland and Mahoney (this volume) found secondary palygorskite and celadonite in Site 459 basalts that they suggest formed during an early oxidative stage of hydrothermal alteration. Later, less oxidative alteration occurred in zones of intense fracturing in the basalts, resulting in the formation of smectites and phillipsite. Heat flow measured by Uyeda and Horai (this volume) in both Holes 458 and 459B was below $1 \mathrm{HFU}$.

Bleil (this volume) measured remanent magnetism in the igneous basement of the fore-arc sites. He found nine separate magnetic units with distinct inclinations in Hole 458-five in the high-magnesian andesites and four in the arc tholeiitic basalts. Although some of these units may be caused by displacement due to faulting, 
many correspond to chemical units in the rocks and are probably representative of secular variation in the Earth's field, thus suggesting a lengthy history of igneous emplacement. Bleil's measurements at Site 459 showed the igneous rocks to have extremely high magnetic intensities (consistent with their high iron enrichment) with shallow inclinations of both normal and reversed polarity.

Takigama and Ozima (this volume) attempted to agedate igneous rocks from Sites 458 and 459 using the ${ }^{40} \mathrm{Ar}-{ }^{39} \mathrm{Ar}$ method. A sample from Site 459 yielded neither a plateau age nor an isochron because of alteration and air contamination. A sample from the highmagnesian andesites near the top of the igneous section in Hole 458 yielded an isochron age of $33.6 \mathrm{~m} . \mathrm{y}$., and a sample from the basalts deeper in the hole yielded an age of approximately $20 \mathrm{~m}$.y. Almost certainly the basalt age (and probably both these radiometric ages at Site 458 ) represents the time since secondary mineralization in these highly altered rocks, not the time of emplacement.

\section{Mariana Trough}

Several lines of investigation, including observation of bathymetric trends and sediment distribution (Karig, 1971), the presence of fresh tholeiitic basalts (Hart et al., 1972), and heat flow trends (Anderson, 1975), led previous investigators to agree that the Mariana Trough was actively spreading. There were, however, no shallow earthquakes in the basin that were large enough to be detected by the worldwide seismic network, and attempts to correlate magnetic anomalies in the basin were unsuccessful. Thus there has been little evidence or agreement on the rates or geometry of this back-arc spreading.

With more complete bathymetric data available after the IPOD site surveys, Fryer and Hussong (this volume) suggested that the spreading was symmetric and, at $18^{\circ} \mathrm{N}$ latitude, centered at an axial graben trending about $330^{\circ}$ that is somewhat reminiscent of the graben at other slow centers of spreading (e.g., the Mid-Atlantic Ridge). On both sides of this spreading axis the extensional back-arc basin crust is broken by normal faults into approximately north-south trending ridges that are rotated with their steep sides facing the apparent spreading center (see Plate 2, back pocket, this volume). An east-trending bathymetric deep that cuts across the roughly north-trending ridges in the trough had been noticed by Karig (1971; Karig et al., 1978) and Bibee et al. (1980) and is more clearly delineated by Fryer and Hussong (this volume) as an irregularly trending fracture zone produced by an apparently unstable ridge-ridge transform fault system.

Ocean bottom seismometers deployed around this fracture zone recorded numerous small (magnitude less than 3.5) earthquakes with an epicenter pattern (Hussong and Sinton, 1979) consistent with ridge transform spreading geometry.

Bibee et al. (1980) tentatively correlated and dated the anomalies on profiles within $50 \mathrm{~km}$ of the center of the trough and suggested that the seafloor was spread- ing at a half-rate of $1.5 \mathrm{~cm} / \mathrm{y}$. They were not able to correlate these same profiles at greater distances from the spreading axis. Hussong and Fryer (1980), using a larger data set, correlated east-west profiles north of $17^{\circ} 30^{\prime} \mathrm{N}$ latitude and suggested that near $18^{\circ} \mathrm{N}$ the basin was opening at a half-rate of $1.65 \mathrm{~cm} / \mathrm{y}$.

Crustal structure in the Mariana Trough has been measured by Bibee et al. (1980), LaTraille and Hussong (1980), and Ambos and Hussong (in press). All these studies, using different data sets, suggest that the backarc basin has a crustal thickness of about 5-6 km, an unusually thick layer $2 \mathrm{~A}$, and a low (generally less than 8 $\mathrm{km} / \mathrm{s}$ ) upper mantle seismic velocity. The seismic velocity structure of the Mariana Trough crust is, therefore, similar to what has been observed in the slow-spreading Mid-Atlantic Ridge.

Sager (1980) interpreted a free-air gravity profile across the Trough and, using the crustal structure model of LaTraille and Hussong (1980), determined that the density of the crust and upper mantle in this back-arc basin had to be lower than observed in young lithosphere beneath deep ocean basins.

Thus, based on geophysical data, seafloor spreading in the Mariana Trough has many characteristics (a recognizable spreading geometry, morphology, sediment distribution, crustal structure, heat flow, and seismicity) that mimic, but are persistently slightly different from, the geophysical characteristics of slow-spreading mid-ocean ridges. It may be that these back-arc basins are most similar to regions undergoing early stages of slow rifting, such as the Red Sea or the Gulf of California, with the important difference that there is relatively little sediment supplied to the Mariana Trough.

Three drill sites in the Mariana Trough were chosen (Fig. 2) to test the rate and geometry of crustal spreading and determine the history of sedimentation and crustal evolution in the basin. We also hoped that drilling at the site on the eastern side of the basin would penetrate the thick apron of volcanic sediments to provide basement samples permitting comparison of upper crustal alteration with and without (as on the western side) a thick sediment cover.

Sites 453,454 , and 456 all yielded turbidite sequences of volcaniclastic sediments that contain considerable hemipelagic and biogenic components. At all the sites there is a mid-Pleistocene transition from nonsiliceous sediments with low $\mathrm{CaCO}_{3}$ content-indicating deposition at a depth near the level of carbonate compensation -to overlying siliceous ooze.

The spreading history of the Mariana Trough that had been broadly deduced during site surveys was substantiated. Cores from the westernmost site (453) have a decreasing volcaniclastic component, reflecting that site's increasing distance from the volcanic arc as the Trough opened. The increase in rates of sedimentation and volcaniclastic components during the period from about 0.3-0.9 Ma suggests an increase in volcanic activity during that period (Packham and Williams, this volume). The paleontologically determined ages of the basal sediments is over 4.7-5.0 m.y. at Site 453, 0.9-1.6 m.y. at Site 454, and 1.6-1.8 m.y. at Site 456. An age of 
$5.0 \pm 0.2 \mathrm{~m} . y$. was obtained by paleomagnetic observations (Bleil, this volume) for the sediments just above basement in Hole 453, supporting the paleontologic data.

An unresolved inconsistency revealed during the drilling is described by Bleil (this volume) on the basis of his measurement of paleomagnetic inclinations in the sediments. $\mathrm{He}$ found that the deeper sediments at Sites 453 and 454 on the west side of the trough have low inclinations, suggesting strong latitudinal motion to the north during the past $5 \mathrm{~m} . \mathrm{y}$. However, Site 456 and the arc sites seem, by similar measurements, to have had little northward motion during the same period. On this evidence, Bleil (this volume) suggests that the Mariana Trough near $18^{\circ} \mathrm{N}$ has opened in a northwest-southeast direction, which appears to be inconsistent with other data and interpretations.

The igneous basement rocks at Sites 454 and 456 are vesicular, sparsely phyric plagioclase and olivine-plagioclase pillow basalts and flows. At Site 454 the igneous rocks are fresh and interbedded with sediment layers. Two distinct chemical types, one typical of depleted mid-ocean ridge or marginal basin tholeiites and the other similar to island arc basalts, were recovered at Site 454 (Wood et al., this volume), implying simultaneous supply of two fundamental magma types to this site in the center of the Mariana Trough, now about $125 \mathrm{~km}$ from the present volcanic arc.

Heat flow at Site 454 was only $0.06 \mathrm{HFU}$ (Uyeda and Horai, this volume). This low value, in addition to other drilling characteristics, leads Uyeda and Horai to conclude that seawater at Site 454 flows downhole into highly fractured, apparently highly permeable, basement rocks.

The basalts at Site 456 had been hydrothermally altered to chlorite-calcite-quartz-pyrite assemblages. The basal sediments are also highly altered and contain wairakite, which suggests to Natland and Hekinian (this volume) that alteration temperatures may have been as high as $200^{\circ} \mathrm{C}$. Two holes, only 200 meters apart, were drilled at Site 456 and yielded heat flow values of 1.1 and $2.7 \mathrm{HFU}$ (Uyeda and Horai, in press). This variability, verified by later surface heat flow measurements yielding local values ranging from 0 to $50 \mathrm{HFU}$ (Hobart et al., 1979), implies that hydrothermal activity is still in progress. The extent of hydrothermal alteration diminishes quickly upward in the sediments and downward in the igneous rocks.

Site 453 , instead of yielding the anticipated juvenile Mariana Trough basaltic crustal rocks, cored 86 meters of a complex coarse gabbro-metabasalt polymict breccia overlying 62 meters of metavolcanic breccias, which in turn overlay 18 meters of gabbroic breccia containing a $1.5-\mathrm{m}$ interval of sheared altered noritic gabbro. The basalts and most of the gabbros are metamorphosed to greenschist facies assemblages, and much of the sequence has also undergone hydrothermal alteration, causing retrograde metamorphism to a lower greenschist facies. A downhole heat flow measurement of only 2.7 HFU was obtained by Uyeda and Horai (this volume), but subsequent surface measurements (reported by Ho- bart et al., 1979) were high and variable and may again indicate that the hydrothermal circulation that altered the rocks is still active.

The metabasalts and gabbros at Site 453 are geochemically related to those recovered from Site 451 , on the West Mariana Ridge, and from Sites 460 and 461 on the inner (island arc) wall of the Mariana Trench (Wood et al., this volume).

The apparent high degree of metamorphism and the chemical affinities of these rocks suggest that the igneous basement at Site 453 is composed of island arc rocks that were emplaced at their present location during the early rifting of the Mariana Trough. Seismic reflection profiles over Site 453 show reflectors below those depth penetrated by the drill, so it is uncertain whether the arc-derived breccias are representative of the upper crust beneath Site 453 , or whether there are back-arc basin basalts at greater depth.

\section{DISCUSSION}

\section{Mariana Arc Volcanism}

Both sites drilled on the Mariana fore-arc cored completely through the sediment cover and achieved substantial penetration into igneous basement. Although there were some hiatuses (Fig. 4), Hole 458 sampled a nearly continuous section down to lower Oligocene ( $\sim 30-34 \mathrm{Ma})$, and Hole 459B recovered sediments down to upper Eocene $(\sim 42-45 \mathrm{Ma})$. These sediments provide a geologic record that includes evidence of the level of volcanic activity on the island arc since the Eocene, when the present arc was presumably still part of the Palau-Kyushu Ridge.

Using shipboard core descriptions, we have summarized in Figure 4 the amount of volcanic glass observed in smear slides, comments on occurrence of ash layers, tuffs, etc., and sediments. At both sites sediments deposited since the earliest late Pliocene ( $0-4 \mathrm{Ma}$ ) contain high percentages of volcanic glass. Both sites have sedimentary hiatuses in the lower Pliocene, but the few upper Miocene (8-7 Ma) sediments recovered from Hole 458 also have abundant glass. From the upper Miocene down to the lower Oligocene sediments just above basement (8-33 Ma), only scattered samples are high in volcanic glass in Hole 458. Occasional ash layers are, however, observed throughout the Miocene and upper Oligocene, with a short abundant period near the Oligocene-Miocene boundary $(\sim 24-22 \mathrm{Ma})$. It is only for a section in the middle of the Oligocene (from about 31-27 Ma) that no glass, ash layers, or tuff are observed in Hole 458.

The results from Hole 459B are somewhat different from those of Hole 458. In Hole 459B abundant volcanic glass is observed down to the lowest Miocene and even includes a portion of the upper Oligocene $(\sim 27-24$ Ma). Hole 459B is similar to Hole 458 in recovering very little volcanic material from sediments deposited in the early late Oligocene (30-27 Ma). No sediments were recovered from the latter part of the early Oligocene (34.5-30 Ma), but all the deeper sediments, dating back 


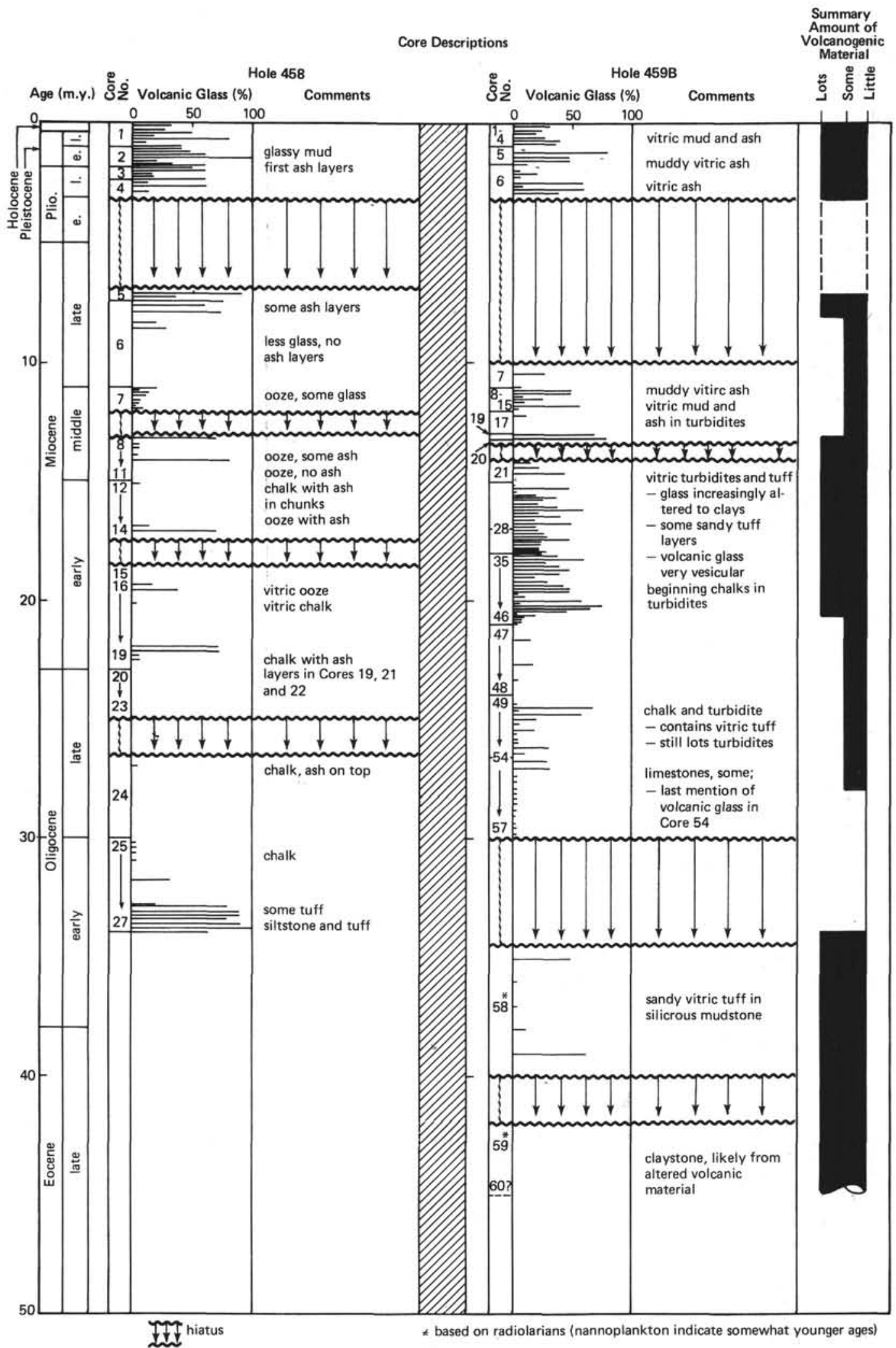

Figure 4. Summary of sediment descriptions for Holes 458 and 459B on the Mariana fore-arc. Comments on ash layers, ash and tuff distribution, and alteration products from volcanic material are abstracted and combined with the percentages of volcanic glass in smear slides from the cores. A tick mark was placed at the location of every significant smear slide, so locations with less than $5 \%$ volcanic glass generally indicate negligible glass. 
to the late Eocene, contain evidence of nearby volcanic activity.

In order to check the correlation of episodes of volcanic activity with the episodes of back-arc spreading noted by Karig (1975) and Scott et al. (1980), we have summarized our results and those of other sampling efforts in Figure 5. We suggest that there has been continuous volcanic activity in the Marianas since the late Eocene but that there are times of apparent reduced distribution in the sampled areas (DSDP sites and the present Mariana Islands) of material derived from volcanism in the periods from 32 to $21.5,13-8$ and $7-6$ (or 5?) Ma.

Although our data are similar to those of Scott et al. (1980), Figure 5, we do not observe a strong correlation in Figure 5 between waning volcanism and spreading. There may, however, be a relationship between the amount of volcanic material distributed around the arc and the earlier stages of back-arc spreading. If such a relationship exists, perhaps the trends in the distribution of volcanic products are not caused by changes in the level of volcanic activity but are instead a secondary effect of difficulties in transporting volcanic material during the rifting of island arcs. The arcs rift near the axis of volcanism, sundering and causing subsidence of the arc volcanoes. Although volcanism continues uninter- rupted, arc lavas are erupted for some time in deep water in the juvenile rift. Very little glass or ash is then available for subaerial, or even submarine, transport to nearby shallower arc regions. At this earliest rifting stage the axis of back-arc spreading and the axis of arc volcanism are in essentially the same location. After a period of back-arc spreading, the center of spreading migrates from the axis of arc volcanism, which must remain fixed relative to the descending oceanic slab. When the volcanic centers are no longer subject to subsidence and are once again constrained by the conduits that bring magma up from $100-125 \mathrm{~km}$ depth, the arc volcanic edifices build up relative to the surrounding arc massif and become an increasingly important source of regional sediment supply. When the arc volcanism becomes subaerial, the effect on regional sedimentation is even greater. The increase in volcanic material in Mariana Trough sediments beginning $\sim 1 \mathrm{Ma}$ (Packham and Williams, this volume) may mean that the present arc volcanoes rose close to and above sea level, permitting more subaerial transport of glass and ash.

A sketch of the formation and opening of the present Mariana arc system (Fig. 6) illustrates the building and rifting of the arcs. Note that back-arc rifting tends to begin near the axis of arc volcanism. Certainly for this $18^{\circ} \mathrm{N}$ Mariana system transect, the arc volcanic axis is

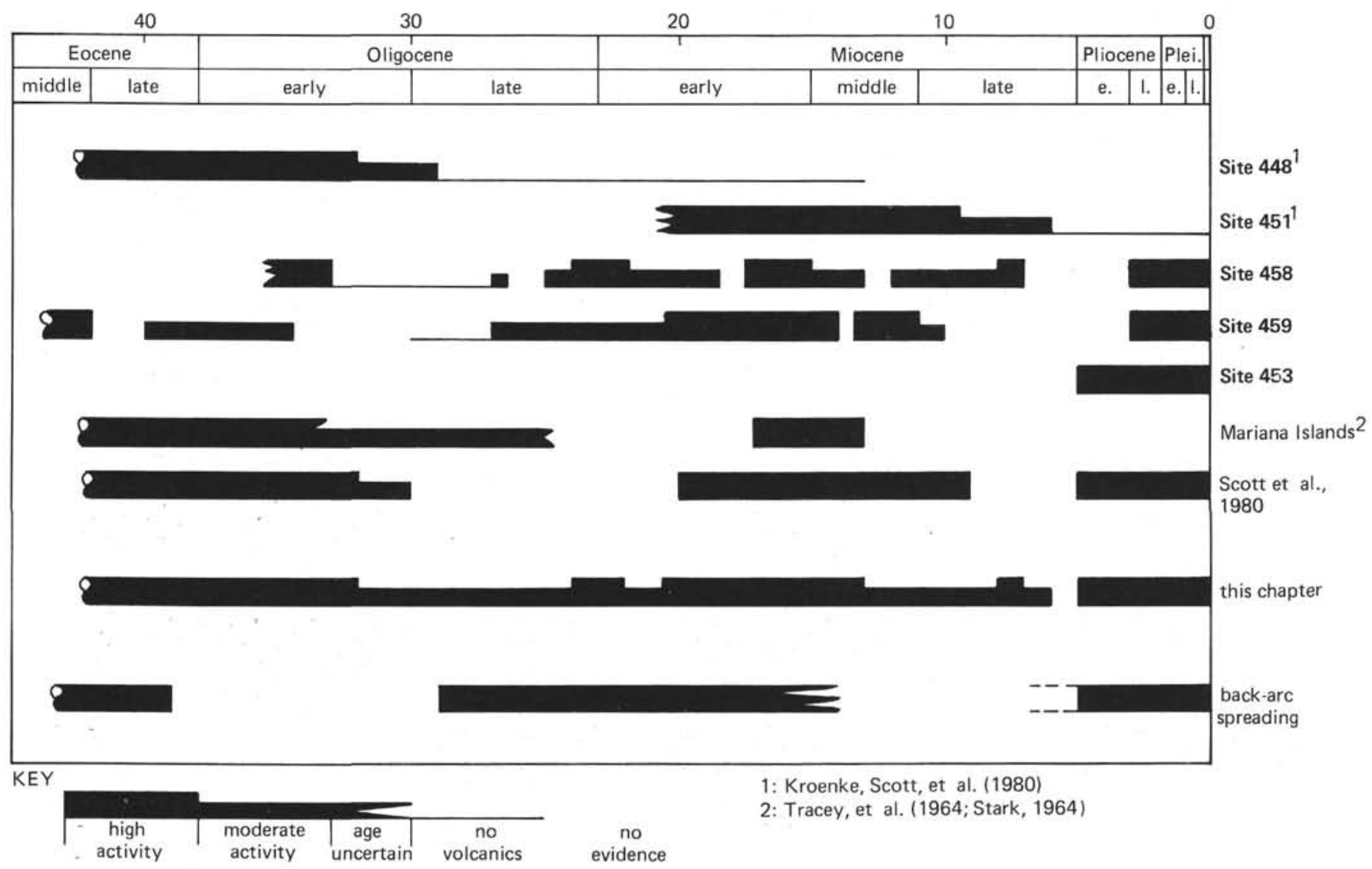

Figure 5. Summary of apparent level of Mariana arc volcanic activity. Width of bar for drill holes indicates amount of material of volcanic origin in sediments, which is a function of the ease of transport of volcanic output as well as of the level of volcanic activity. The summary levels interpreted for this chapter include all DSDP core data plus information from onshore studies of the Mariana Islands. 


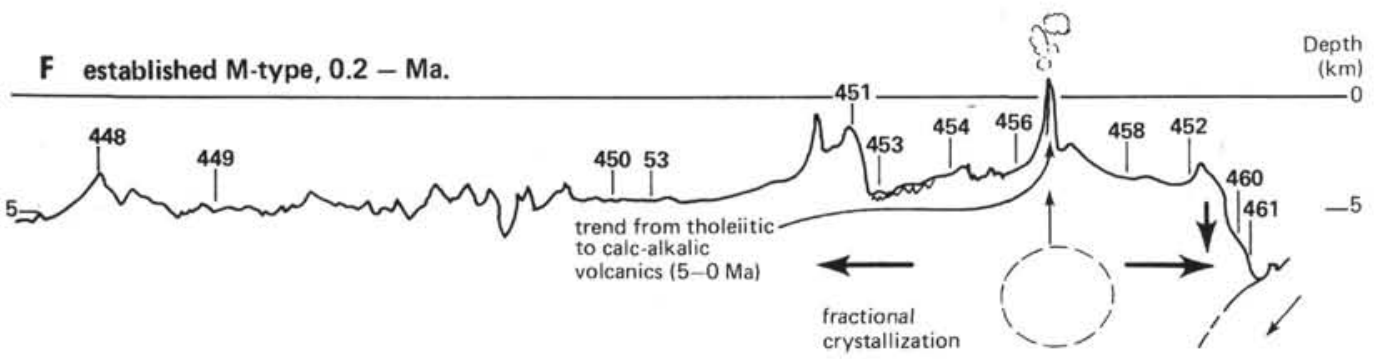

E M-type, $6 \mathrm{Ma}$

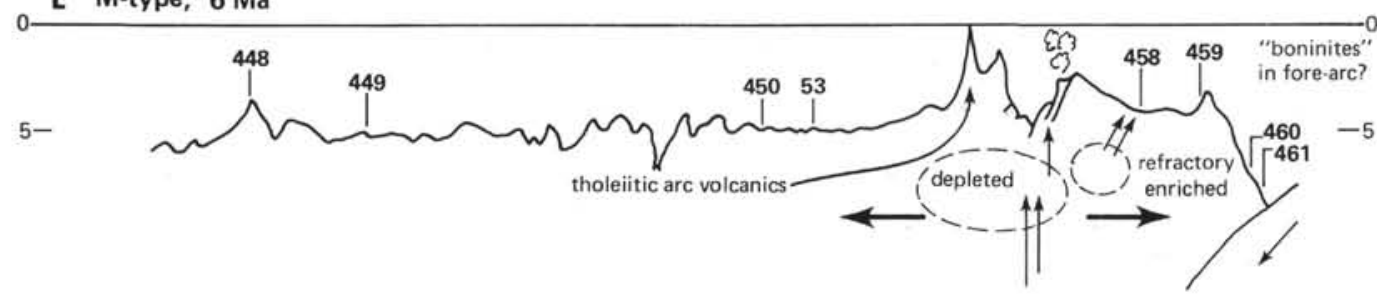

D C-type, $13 \mathrm{Ma}$

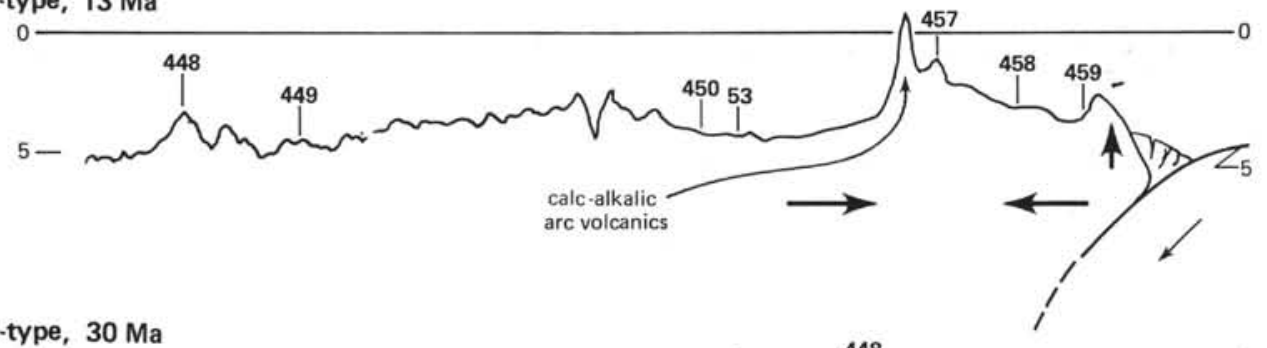

C M-type, $30 \mathrm{Ma}$

B C-type, $40 \mathrm{Ma}$

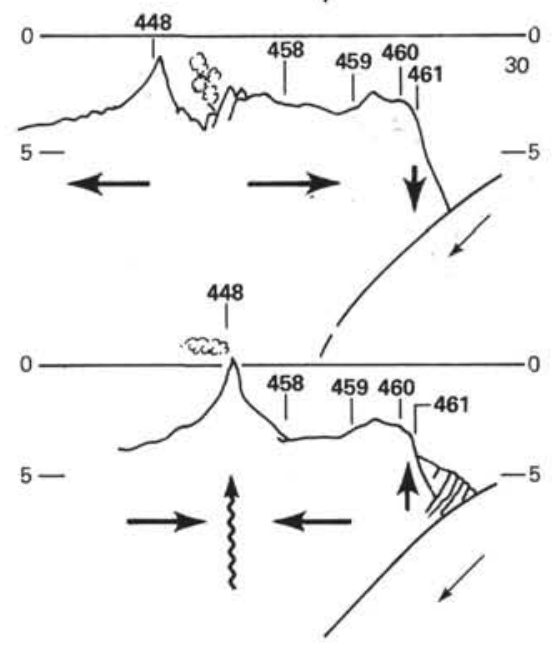

A Initial Subuction, $45 \mathrm{Ma}$ ?

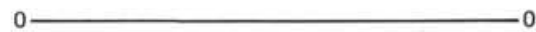

initial subduction

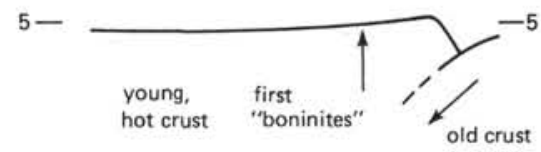

Figure 6. Schematic diagram of history of opening of the Mariana arc system. A. Initial subduction of old Pacific plate beneath recently formed West Philippine basin crust in the Eocene, producing first Palau-Kyushu volcanism and first emplacement of "boninites" (high-Mg andesites) on the fore-arc. B. By the late Eocene the arc massif has built up, still in a Chilean-type (C-type) compressive stress state, producing uplift, sediment accretion(?), and a probable trend toward calc-alkaline arc volcanism. C and E. In early late Oligocene the arc goes into a Mariana-type (M-type) extensional episode resulting in subsidence, initiation of back-arc spreading, movement of depleted mantle into the subarc magma chambers, eruption of back-arc basalts and arc tholeiites in the juvenile rift, possibly emplacement of "boninites," and tectonic erosion of the accreted sediments and (perhaps) some arc material. This stage of the cycle is repeated at the end of the Miocene (E). D. When the regional stress field changes back to compression, the back-arc spreading stops and the arc tectonics become C-type, repeating the activities of the late Eocene (B). F. The present arc is in an established M-type extensional stress state, producing subsidence, tectonic erosion of the trench wall, back-arc spreading that generates basalts similar to MORBs, and a trend from eruption of tholeiites to eruption of calc-alkaline magmas on the arc. 
the obvious zone of greatest lithospheric weakness. The arc volcanoes build on back-arc basin crust and keep it hot, whereas the rest of the back-arc basin goes through a long period of cooling after the end of the previous spreading episode.

Natland and Tarney (this volume) note that there are both tholeiitic (iron-enriched) and calc-alkalic (not iron-enriched) rocks on the Palau-Kyushu and Mariana arcs and calc-alkalic rocks on the West Mariana Ridge. Packham and Williams (this volume) see a progression from tholeiitic to calc-alkalic glass in the sediments of Hole 453. This suggests a trend of tholeiitic to calcalkalic volcanism associated with each stage of arc rifting and construction of new arc volcanoes (Natland and Tarney, this volume). There are even high-magnesium andesites similar to those of the "boninite type" recovered in Hole 458 (which Meijer et al., this volume, associate with initial subduction processes) in the lower Miocene Umatak Formation on Guam (Stark, 1964; Meijer, 1980 ) and in 10.8 m.y. old rocks dredged off Guam (Beccaluva et al., 1980). Thus the arcs seem to go through a complete magmatic evolution during each cycle of arc building and back-arc spreading. Although the timing and interrelationship of the various magmatic events are confusing, it may be that "boninite" extrusion occurs on the fore-arc not only during initial subduction but also during the first stages of arc rifting at the onset of back-arc spreading (Beccaluva et al., 1980). Splitting of the arc introduces heat from below, and water from above, into an alreadly refractory and enriched mantle beneath the arc and fore-arc, allowing formation of "boninites." As spreading proceeds, the mixture of back-arc basin (MORB-type) basalts and arc tholeiites erupting in the initial rift is separated by the retreat of the back-arc spreading center. When this happens, the more constrained arc magma plumbing produces tholeiitic magmas that build stratovolcanoes, the arc crust thickens, and the magma sources undergo fractional crystallization that culminates in a shift to calc-alkaline composition (Fig. 6). Geochemical trends in arc volcanism are more fully discussed in Natland and Tarney (this volume). Their possible relationship to tectonic trends warrants considerably more investigation.

\section{Fore-arc Tectonics}

The Mariana fore-arc region near $18^{\circ} \mathrm{N}$ has two basic characteristics that were unanticipated when Leg 60 was planned. First, there are many large seamounts of questionable origin scattered between the present volcanic arc and the trench axis. Second, there is no evidence of accretion of Pacific ocean plate material onto the overriding arc. The arc seems to have been formed entirely by volcanic activity and may even be subject to tectonic erosion as bits of the leading edge of the overriding plate are subducted with the Pacific plate.

The distribution of fore-arc seamounts is an aspect about which we have little hard data. Thus we can only speculate as to their origin. Hussong (this volume) and Hussong and Fryer (this volume) note that many of these features are roughly conical in shape, rise as much as $2-3 \mathrm{~km}$ above the surrounding fore-arc, and show magnetic and gravity anomalies that suggest they are composed of igneous rocks. These characteristics lead us to believe that the fore-arc seamounts are volcanoes, yet some of them exist so close to the trench axis that the top of the subducted ocean plate is only $15-30 \mathrm{~km}$ beneath the seafloor. We do not believe the seamounts are allochthonous, because we have found no evidence for transfer of ocean plate material to the arc, as described later in this section. Assuming the seamounts are volcanic and autochthonous, three models for their formation come to mind (Fig. 7):

1) The magma comes from deep beneath the axis of the volcanic arc (Fig. 7A) but migrates through the forearc before reaching the seafloor near the trench axis.

2) The fore-arc volcanoes are old features that were formed as typical arc axis volcanoes when considerably more fore-arc existed east of the present trench axis (dotted lines, Fig. 7B). Since then, tectonic erosion of the fore-arc has effectively moved the trench axis, Benioff Zone, and zone of arc magma genesis to its present position relative to contemporary arc volcanism. A version of this model that involves less tectonic erosion would postulate magma genesis at shallower depths beneath the arc during the initial stage of subduction (such as Meijer et al., this volume, describe for the formation of the bronzite andesites in Hole 458).

3) The source of the fore-arc volcanoes is deep in the oceanic lithosphere (Fig. 7C), where tensional fracturing of the upper part of the plate (during bending into the subduction zone) has caused release of confining pressure and possible water circulation, resulting in magma genesis.

More sampling and study of these fore-arc volcanoes are required before we can choose between these and any other models explaining fore-arc volcanism.

It should be noted here that, as pointed out by Hussong (this volume), some of the fore-arc seamounts nearest the trench axis have very subdued gravity anomalies. These seamounts do not seem to be of igneous origin and may instead be large diapirs (serpentinite?) or simply blocks of arc sediment somehow uplifted by subduction-related tectonic activity.

Implicit in the foregoing discussion is our belief that Leg 60 showed that fore-arc is not composed of accreted oceanic material (and thus that the fore-arc seamounts are not chunks of ocean basin igneous rock) and that there is even evidence that the leading edge of the Mariana arc is being tectonically eroded by the subducting Pacific plate. This belief is based on the age distribution, subsidence, tensional deformation, structure, and geochemical character of the fore-arc.

\section{Age Distribution}

The entire basement of the Mariana fore-arc, including the Guam-Saipan-Tinian island trend and Sites 458, 459 , and 460 , is early Oligocene or older. In fact, it seems that the entire fore-arc, which at $18^{\circ} \mathrm{N}$ is nearly $175 \mathrm{~km}$ wide, probably existed in the late Eocene. This indicates that either the initial level of arc volcanism was remarkably high or that the island arc (and related subduction) existed for considerable time before the late 
A

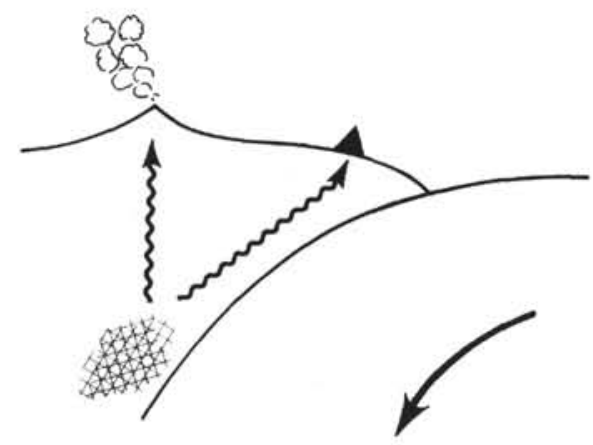

B

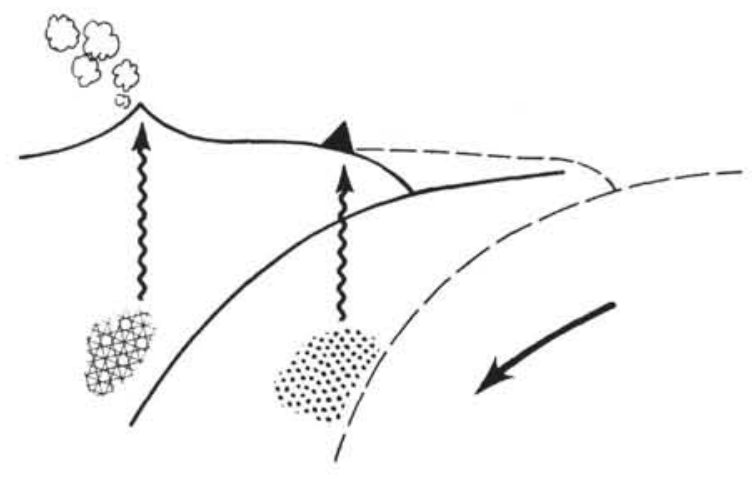

C

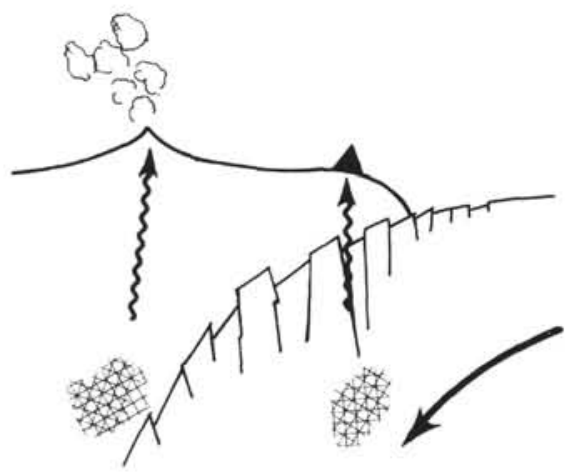

Figure 7. Schematic diagram of origin of volcanism near the trench axis. A. Lateral magma transport from deep subarc source. B. Subarc source when subducting slab is located seaward of present location (evidence for tectonic erosion?). C. Source in fractured oceanic lithosphere.

Eocene $(42 \mathrm{Ma})$. There is no age progression indicative of arc accretion; if anything, the material closer to the trench is older, since the oldest basement is in Hole 459B, $45 \mathrm{~km}$ from the trench axis, and Eocene sediments associated with arc igneous rocks are found at Hole 460 , only $23 \mathrm{~km}$ from the trench. Hole $459 \mathrm{~B}$ is near the trench slope break, and from Hole 460 the trench wall drops at an average angle of about $9^{\circ}$ to the trench axis. There is no room for an accretionary prism of any significance.

\section{Fore-arc Subsidence}

Although Site 458 shows no clear sign of subsidence and may have been above or near the CCD since the Oli- gocene, Site 459 contains abundant calcareous sediment below the present CCD. Unfortunately, we cannot say where the CCD was in the past, and much of the calcareous sediment deep in Hole 459B was deposited as turbidites that may have been deposited too fast for dissolution to occur. Also, the paleomagnetic data (Bleil, this volume) indicate that these old calcareous sediments may have been rapidly deposited when Hole 459B was near the equator. The strongest evidence for subsidence is in Hole 460, where an Eocene-Oligocene sequence of calcareous sediments occurs at a depth of 6500 meters. Although there is no unequivocal evidence that the Paleogene sequence in Hole 460 was not somehow scraped off the ocean plate, the sediments are similar to those sampled from the shallower fore-arc holes and have abundant volcanic glass and ash components, indicating a nearby volcanic source. We assume this source was the Mariana arc. Also, igneous rocks from Site 460 and 461 have arc geochemical affinities. Unfortunately, no depth-definitive benthic foraminifers were recovered in any of the holes.

\section{Tensional Deformation}

No compressional deformation (which would be expected from the formation of an accretionary prism) has been found anywhere on the fore-arc. As noted by Mrozowski and Hayes (1980) and Hussong and Fryer (this volume), seismic reflection records on the fore-arc show exclusively high-angle faulting and no folding. The faults tend to strike parallel to the trench and are more abundant closer to the trench. Near the trenchslope break, the fore-arc faults are preferentially downdropped to the east (toward the trench axis). On the much smaller scale observed in the DSDP cores, normal (tensional) faulting is also predominant and increases closer to the trench and with depth in the holes.

\section{Structure}

Except for some small terraces deep on the inner wall of the trench-which Mrozowski et al. (this volume) believe may be prisms of sediment, based on their slightly different acoustic character-there is no structural evidence for accretion. We did not even observe any sediments ponded in the trench axis, much less scraped off the steep island arc wall of the trench. There were no hints of landward-dipping reflectors in any of the seismic data from the trench wall, nor did we find repeated or overthrusted sections in the cores from Sites 460 or 461.

\section{Igneous Rock Geochemistry}

As described by Wood et al. (this volume), all the igneous rocks from the fore-arc and trench wall sites that were analyzed are geochemically identified as derived from the island arc. These include many basement rocks from Sites 458 and 459 . We doubt that true basement was sampled at Site 460 and 461 , but the few analyzed samples from the wide variety of rock types recovered at these sites also have island arc affinities.

In summary, then, we have found no evidence for building up of the fore-arc by accretion of ocean plate 
material. We have found numerous lines of evidence suggesting that subsidence and tectonic erosion of the fore-arc have occurred, but most of this evidence is circumstantial. Considering the thin cover of unconsolidated sediments over the Pacific plate, it is not surprising that there is no substantial sediment transfer to the island arc. Furthermore, the severe bending of the $\mathrm{Pa}$ cific plate prior to subduction produces very large grabens on its upper surface, near the Mariana Trench. Several investigators, including Hilde et al. (1978), Jones et al. (1978), and Schweller and Kulm (1978), have suggested that such irregular relief on the descending slab may serve to abrade the overriding slab and even trap arc material and carry it down the subduction zone.

\section{Mariana Trough Back-arc Spreading}

As noted earlier, the axial graben that Fryer and Hussong (this volume) identify as the center of Mariana Trough spreading at $18^{\circ} \mathrm{N}$ has a strike of $330^{\circ}$. This implies that the directions of back-arc spreading in this region are $60^{\circ}$ and $240^{\circ}$. Figure 8 shows the distances from the spreading axis, in the direction of spreading, of the three drill sites in the Mariana Trough where the age of the basal sediments were determined. The determinations provide a minimum age for the formation of the underlying igneous basement and thus can be used to calculate a maximum crustal spreading rate. Although based on only three points, Figure 8 shows that at $18^{\circ} \mathrm{N}$ the seafloor spreading normal to the $330^{\circ}$ trending axial graben is symmetric and has had an average maximum rate of $2.15 \mathrm{~cm} / \mathrm{y}$. for the past $5 \mathrm{~m} . \mathrm{y}$.

It is also apparent from the limited set of three basement drill holes that, as would be suspected from the existence of magnetic seafloor spreading anomalies, the spreading center magmatic activity occurs in only a narrow zone of near-zero-age crust. The apparent sequence of lava flows penetrated at Hole 454A were probably all emplaced within less than $300,000 \mathrm{y}$. (Bleil, this volume) - that is, within $10 \mathrm{~km}$ of the spreading axis, at the calculated spreading rate. There was no other evidence of back-arc basin volcanism away from the spreading axis.

As noted by Hussong (this volume), regional bathymetric trends and the character of geophysical anomalies suggest that the eastern edge of the Mariana Trough is $20-30 \mathrm{~km}$ east of the present axis of arc volcanism. This means that the crust beneath the arc volcanoes is produced either by emplacement of back-arc crust at a spreading center or by stretching, subsidence, and thinning of pre-existing volcanic arc crust during initial back-arc rifting. The actual origin of this crust may be a combination of thinning crust and emplacement of new crust.

A generalized sketch of a structural cross section of the Mariana Trough is included in Figure 8. Note that the present arc volcanoes are situated about the same distance east of the axis of the Mariana Trough as Site 453 is to the west. If the Mariana Trough is structurally symmetric at $18^{\circ} \mathrm{N}$ (except for the volcanic pile that has grown upon and probably caused subsidence of the eastern side of the Trough), then the crust beneath the volcanoes may be similar to that at Site 453 . At this point, however, the origin of the basement at Site 453 remains in question. The petrology and geochemistry of the basement rocks in Site 453 show that they are of island arc origin. However, except for the scant occurrence of reworked Eocene and Oligocene nannofossils just above basement, the cored sediments at Site 453 were all deposited after the Mariana Trough began to open, posing the question of what happened to the sediment that must have covered the arc prior to rifting. The intense geothermal activity that once occurred around Site 453 (and may still be occurring) may also result from emplacement of magma near the site. As noted in the site chapter, geophysical profiles over the pond drilled at Site 453 show seismic reflectors below the depth reached by the drill. This deep interface could be igneous rock that was emplaced somehow during the early rifting period, although the mechanism for its emplacement is difficult to explain.

The symmetric and steady spreading summarized in Figure 8 imply that the back-arc spreading began in the latest Miocene and support our interpretation that the present arc volcanoes are built on crust that is either stretched and subsided arc or recently emplaced backarc basin crust. Thus, at the beginning of rifting, the locus of back-arc spreading and arc volcanism were along the same line. As extension continued and the back-arc opened, the spreading occurred as a reaction to the tension and was symmetric, causing the spreading center to stay near the center of the Mariana Trough. Meanwhile, the axis of arc volcanism stayed in about the same position, governed by the location of the downgoing slab and by the widely spaced conduits (the present arc volcanoes are at a N-S spacing of about 60 $\mathrm{km}$ ) up which magma may travel from depths probably exceeding $100 \mathrm{~km}$.

A summary plot of sediment accumulation at the three significant Mariana Trough sites is shown in Figure 9. In this figure the time scale is in millions of years since the beginning of sedimentation. In all cases there is a significant decrease in the rate of sedimentation with age. Some of this declining sedimentation rate, particularly in Hole 453, can be attributed to the increasing distance from the hole to the arc volcanoes as the back-arc basin opens. Packham and Williams, this volume, note that the proportion of volcanic glass in the sediments in Sites 453 and 454 decreases with age, perhaps because of this same displacement away from the volcanoes. However, Holes 456 and 456A, which do not change position relative to the arc, show the same decline in sedimentation rate.

Part of this decreasing rate of sedimentation may be because most of the sediment transport is by turbidite flow. As the lowest areas in the back-arc basin fill with turbidites, the region covered by sediment ponds increases, so the ratio of turbidite source areas to turbidite deposition areas decreases, causing an apparent decrease in sedimentation. Another cause of high sedimentation rate in these holes during the first half-million years may be that they were located in an axial depression in the Trough similar to the present axial graben. If 


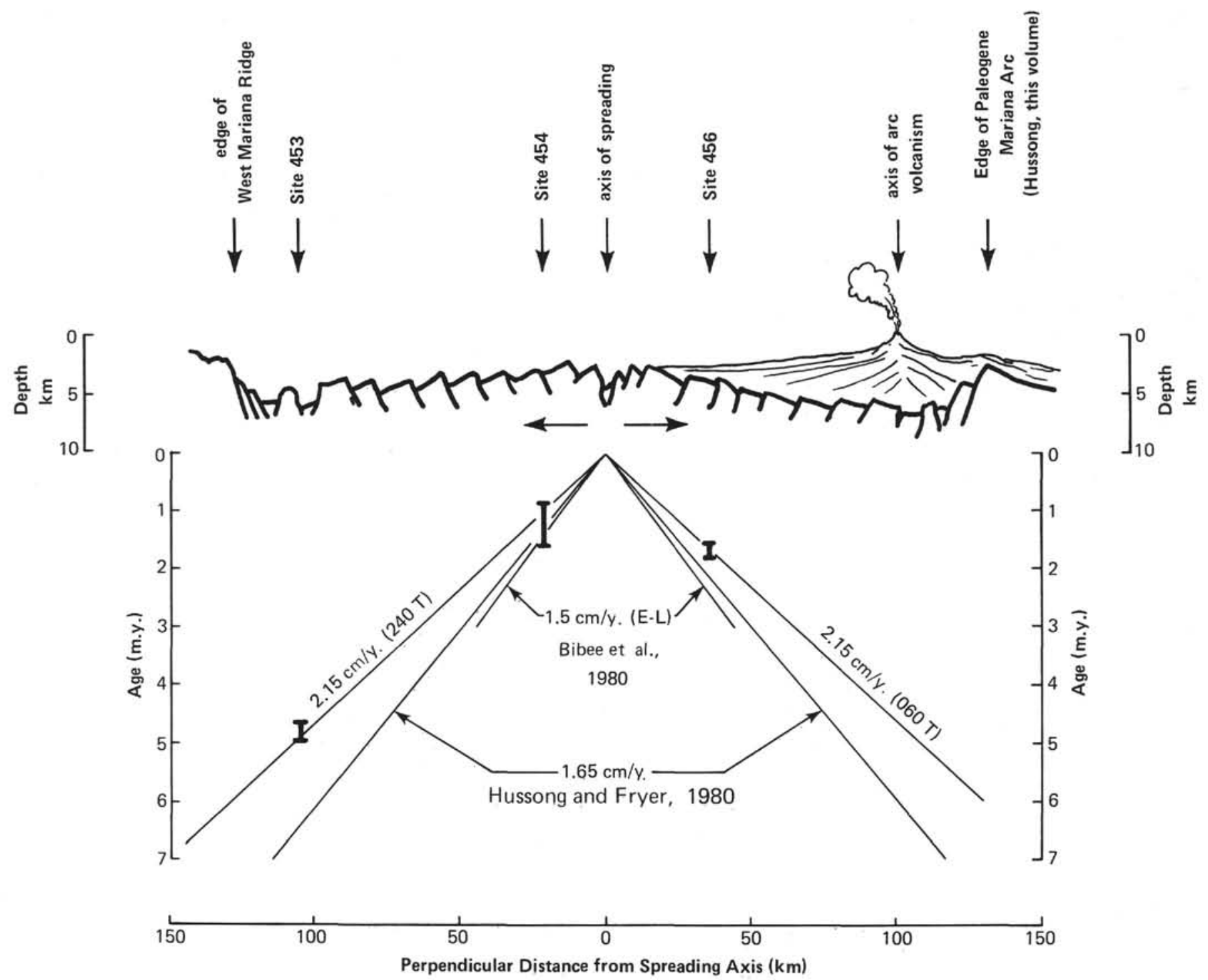

Figure 8. Schematic diagram of back-arc spreading in the Mariana Trough. Error bars for the age of the crust are the paleontologic age range of the basal sediments in that hole.

it is an axial graben, a site may receive volcaniclastic sediments spilling directly from the apron of sediments extending from the arc volcanoes to the edge of the graben. As the back-arc spreads, the site moves away from and is uplifted out of the graben. Once uplifted west of the graben, the site is isolated from bottomtransported volcaniclastics. For Sites 453 and 454, the axial graben blocks any bottom transport of volcaniclastics from the arc. Site 456 is on a local high selected for drilling because its elevation isolated it from bottom-transported volcaniclastics.

It has not been resolved whether the Mariana Trough is opening in a manner that can be rigorously modeled using rigid plates. Some ridge-ridge-transform geometry seems to exist, but the many complexities suggest that the geometry is not stable. Focal mechanism for two shallow earthquakes in the northern part of the Mariana Trough have been determined by Seno and Eguchi (in press), and are consistent with the east-west extension. Considerably more data, particularly mag- netic profiles and high resolution bathymetric plots, are probably required before the geometry of opening in the Mariana Trough can be defined.

\section{GENERAL RESULTS OF IPOD ACTIVE MARGIN DRILLING}

The seven legs of active margin drilling thus far conducted during the IPOD phase of the DSDP have produced a huge amount of data that we are only begining to digest. Of these Challenger cruises, Legs 56, 57, 66, and 67 were in trench and fore-arc areas; Legs 58 and 59 were in back-arc areas; and Leg 60 sampled trench, fore-arc, and back-arc regions. After all this work, the most important basic finding is one that we should have anticipated: The nature of various subduction zones is quite diverse. However, although all subduction zones are not the same, some important relationships are beginning to emerge.

Uyeda and Kanamori (1979) point out that there are basically two different modes of subduction defined by 


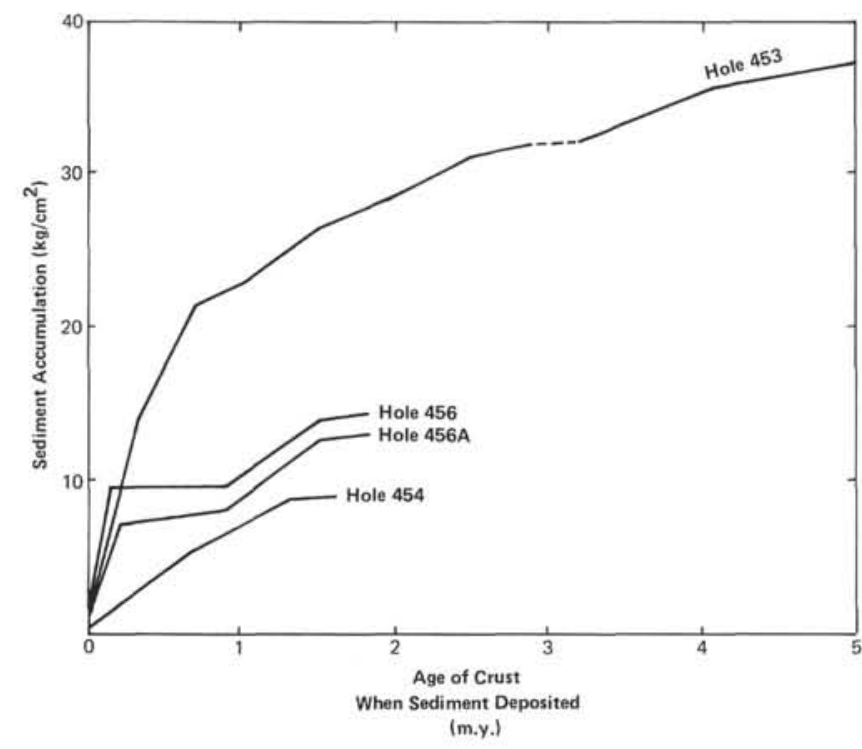

Figure 9. Sediment accumulation through the history of Mariana Trough drill sites. Zero age is the time of deposition of the basal sediments.

the existence of actively spreading back-arc basins that indicate whether the tectonic stress in the back-arc region is tensional or compressional. They interpret this fundamental difference as a function of the degree of coupling between the subducting and the overriding plates. This interpretation is based on the remarkable fact that the truly interplate great earthquakes occur only in subduction zones without active back-arc basins. In fact, over $95 \%$ of the worldwide release of seismic energy occurs in the subduction zones that have no back-arc spreading.

Uyeda and Kanamori (1979) named these two classes of subduction zones "Chilean-type" and "Marianatype." With some reservation, they may also be called "high stress regime" and "low stress regime" subduction zones (Ben-Avraham and Uyeda, in press). Uyeda (in press) has attempted to generalize all subduction zone processes into such a scheme, calling it "comparative subductology."

There are several additional general differences between these two types of subduction zones:

1) The present-day tectonic stress inferred from the mechanisms of shallow earthquakes in overriding plates is compressional in Chilean-type (C-type) margins and tensional in Mariana-type (M-type) margins (Uyeda and Kanamori, 1979).

2) The dip of the associated Benioff Zone is steeper for M-type than for C-type margins.

3) Volcanism is more andesitic in C-type and more bimodal basalt-rhyolite in M-type margins.

4) Porphyry-copper deposits occur in C-type margins and massive sulphide deposits in M-type margins, and the distribution of the ore types is mutually exclusive (Uyeda and Nishiwaki, 1980).

5) Late Quaternary coastal uplift is larger for C-type than for M-type margins by more than one order of magnitude (Yonekura, in press).
Three processes have been suggested to explain the differences in coupling between converging plates and thus the causes of the two modes of subduction:

1) The difference in the strength of coupling may be a function of difference in nature of the contact zone between the two plates. For instance, Kanamori (1977) suggests that the different modes of subduction represent different stages of an evolutionary process wherein subduction starts with low-angle thrusting of the C-type mode and, as the process continues and coupling gradually weakens, changes to M-type subduction.

2) The age of the subducting plate controls the mode of subduction (Molnar and Atwater, 1978). The older the plate, the colder and heavier it is, so the more likely it is to sink with greater speed and less coupling with the landward plate, giving rise to M-type subduction. Conversely, when the subducting plate is younger, C-type subduction will result.

3) The motion of the landward plate relative to the trench line controls the mode of subduction (Chase, 1978; Uyeda and Kanamori, 1979). In this model, if the landward plate tends to move away from the trench line, as with the Philippine Sea plate, M-type mode of subduction occurs, whereas when the landward plate advances toward the trench, as with the South American plate, the mode is C-type. We believe that when the ocean plate slab sinks to great depth in the mantle, it becomes fixed relative to any lateral movement within the mantle. Since motion in the deep mantle (aesthenosphere) is probably much slower than surface plate motions, the position of the trench line associated with a large subducted slab may be regarded as virtually stationary. Thus the relative motion of the upper plate and the trench line can be approximated by the absolute velocity of the upper plate alone. Figure 10 shows the absolute velocity vectors of the circum-Pacific upper plates (Fitch, 1972; Minster et al., 1974). There is a strong correlation between retreating overriding plates and M-type margins.

It is probable that all three processes exert some influence on styles of subduction. Recently, Dewey (1980) combined factors (2) and (3) to develop a general description of the problem. Factor (1) must be inherently influential on the subduction process and may explain the cyclic nature of arc evolution (Kobayashi and Isezaki, 1976; Niitsuma, 1978). However, if factor (1) were the only important process, one would have to prove that similar cycles have taken place at every subduction zone, including the Peru-Chile zone. This does not seem to be the case. Factor (2) is physically sound and well supported to a first approximation by present-day data. It may be difficult to explain the episodic nature of back-arc spreading or the time variation of the mode of subduction from one type to another without having recourse to one of these processes. Factor (3) is probably the mechanism best suited for producing episodic back-arc spreading, since it is dependent on the absolute velocity of the landward plate. For instance, because the absolute velocity of the South American continent has probably been steady since the opening of the Atlantic Ocean, the mode of subduction on its western coast 


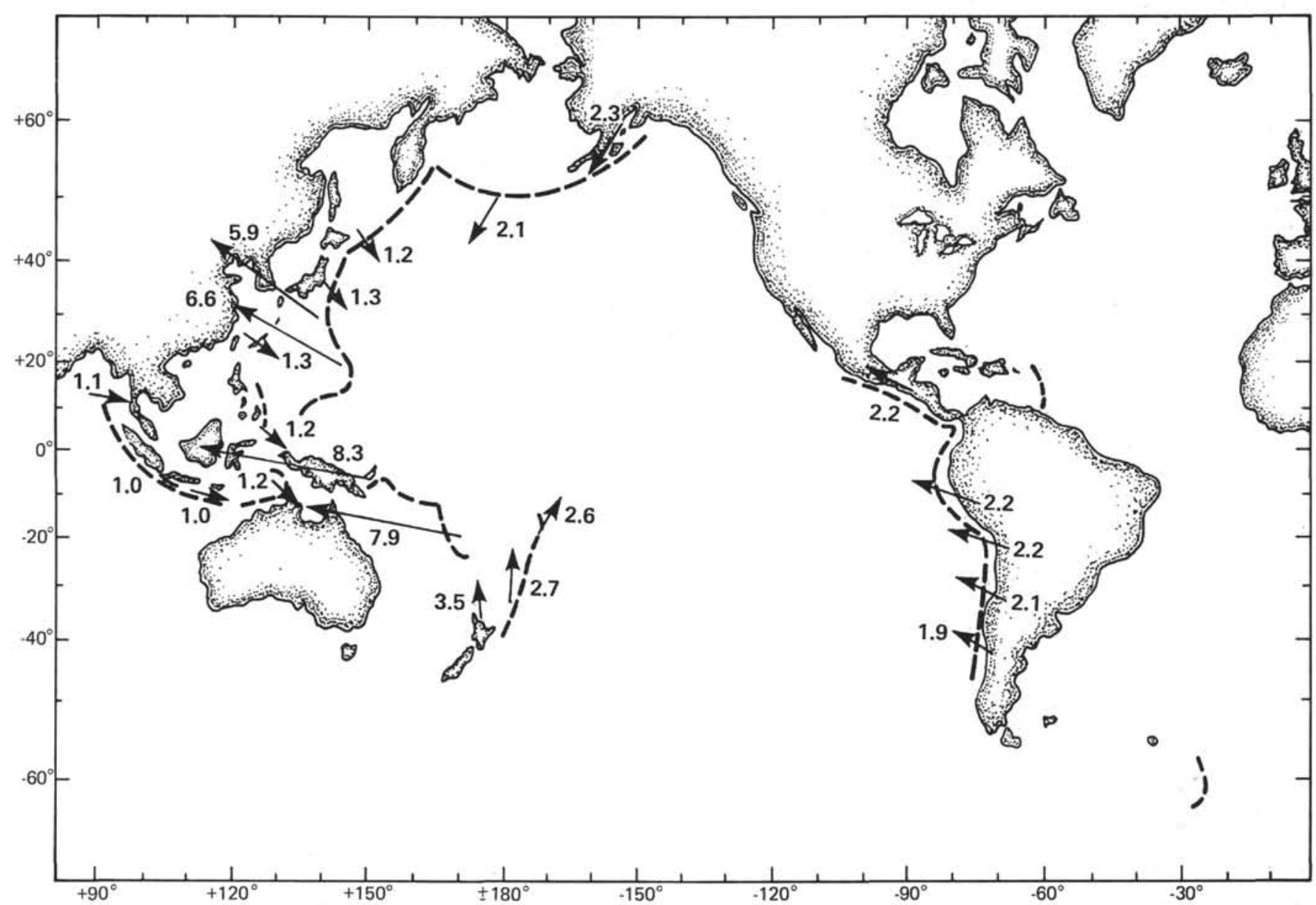

Figure 10. Absolute velocity vectors in cm/y. of the overriding plate in Pacific subduction margins (from Fitch, 1972; Minster et al., 1974; Uyeda, in press).

should have been C-type. On the other hand, the absolute velocity of the eastern margin of the Eurasian plate-relevant to our discussion of western Pacific subduction zones-is very small at present (Minster et al., 1974). Therefore with only slight variation in motion its velocity could have changed sense and been in the direction away from the trench line in the recent geologic past (such as during the opening of the Sea of Japan).

In addition to these global tectonics, it must be noted that all the subduction zones seem to have some kind of built-in mechanism for generating extensional stress fields in their immediate back-arc regions, as shown by the many examples of stress gradients transverse to the trend of arcs (Nakamura and Uyeda, 1980). Upper mantle wedge flow (McKenzie, 1969; Sleep and Toksöz, 1973), diapirism or magma upwelling in the back-arc (Hasebe et al., 1970; Karig, 1971), excess mass brought in by mantle flow (Boström, 1971; Ida, 1978), and temperature anomalies (Artyushkov, in press; Carlson, in press) may be examples of such a mechanism. Probably a complex balance of all these forces determines the actual stress in back-arc area.

\section{Trench and Fore-arc}

An extremely significant result of recent DSDP trench drilling is that it established the history of vertical movements, sediment subduction, and extensional tectonics in fore-arc regions. The occurrence of widespread volcanism in fore-arcs is also an important discovery.

Site 438 and 439 , on the Japan Trench slope, have subsided 3000 meters in the past 25 m.y. (Keller, 1980). (The present episode of subduction may have started approximately $42 \mathrm{Ma}$ ). Drilling in the Mariana Trench and the Middle America Trench off the coast of Guatemala also suggests that these areas have undergone subsidence. This subsidence may have been caused by tectonic erosion of the leading edge of the overriding plate (Hussong et al., 1976; von Huene et al., 1980; Hussong and Wipperman, in press). Langseth et al. (in press) propose further that cooling of the upper mantle by the subducting cold plate plays a first-order role in fore-arc subsidence.

Superimposed on this trend toward subsidencewhich if Langseth et al. are correct may be common to all trenches-is some uplift, detected from DSDP benthic foraminiferal data on the Japan Trench (von Huene et al., 1980) and the Middle America Trench off Mexico (Moore, Watkins, et al., 1979). This uplift may be related to a change of the mode of subduction from Mtype to C-type.

Stronger coupling between the two plates should favor offscraping of trench sediments or even ocean 
crust during C-type subduction, whereas weaker coupling may allow easier subduction of sediments and crustal fragments preferentially on M-type margins. Of course, the sedimentary structure in the fore-arc probably depends more heavily on the amount of sediment supply to the trench. The fore-arc of Sumatra, for instance, receives enormous amounts of material from the Bengal Fan and, being C-type, develops impressive forearc accretionary structures (Karig, et al., 1979). Yet the actual Chile margin does not have a well-developed accretionary prism despite being the "original" C-type margin, probably because of the small supply of sediments from inland (Kulm et al., 1977).

The lack of an accretionary prism in the Andean margin may also be related to the occurrence of tectonic erosion. Since abrasive erosion of the landward plate should be more likely when the coupling of the plates is stronger, accretion on the slope and abrasion from below may be competing processes at typically C-type subduction zones.

A further complication is the graben structure that develops on the subducting plate and that should play an important role in the subduction of sediments (Hilde and Sharman, 1978). It may be that since M-type subduction zones generally have a steeper Benioff Zone, the bending of the subducting plate tends to be sharper, producing more pronounced graben structures. Also, M-type subduction zones are usually more distant from continents, so that the sediment supply from land tends to be sparser. All these factors work against sediment accretion.

In the landward wall of the Mariana Trough we found no sign of accretion of ocean-derived materials. The thick sedimentary wedge on the landward wall of the Japan Trench is composed exclusively of terrigenous and hemipelagic materials at least to the depth of drillhole penetration, and there is very little room left for any accretionary prism (von Huene et al., 1980). These results can be explained, at least partially, in the same way as the subsidence-uplift history: The mode of subduction at the Japan Trench was M-type during most of the Miocene and became C-type only recently (probably during only the past several million years), so that the effective time for possible sediment accretion has been very short.

The supposition that the mode of subduction changed in the Japan Trench several million years ago fits well with the change in the tectonic stress of the Japan area advocated by Nakamura and Uyeda (1980). They mapped the trajectories of maximum horizontal stress in northeast Japan for the present and for the period 21-7 Ma, based on the direction of dikes, faults, and folds; the alignment of volcanoes; and the stress axes of earthquake source mechanisms. As expected for C-type subduction, regional tectonic stress today is compressional in a direction parallel to that of the plate convergence. The tectonic stress for the 21-7 Ma period was clearly tensional in the back-arc region of northeast Japan, suggesting that the mode of subduction at that time was M-type. During this earlier period the fore-arc should have been subsiding, and perhaps at least part of the Sea of Japan was actively spreading.
Figure 11 is a schematic representation of results from the four IPOD Trench transects (off Japan, the Marianas, Mexico, and Guatemala [from Uyeda, in press]). The vertical tectonic history of the Japan Trench (Fig. 11A) was discussed earlier.

As we mentioned, no ocean-derived material was recovered from the Mariana fore-arc drilling (Fig. 11B), and the vertical tectonics in the Mariana fore-arc has apparently been that of subsidence ever since the initiation of the present subduction, probably in the Eocene or earlier. This, in our view, is the typical case for M-type subduction. The detailed history of the Philippine Sea, however, indicates that the spreading of back-arc basins has been episodic. It may be inferred, therefore, that during any pause of spreading (such as $\sim 15$ to $6 \mathrm{Ma}$, between the cessation of Parece Vela spreading and the onset of Mariana Trough spreading) the mode of subduction may have been more C-type. Future detailed investigation of Mariana fore-arc vertical tectonics may well reveal such a history (shown schematically in Fig. $11 \mathrm{~B}$ by a broken line).

In the fore-arc of the Middle America Trench off Mexico (Fig. 11C), landward-dipping reflectors in seismic profiles suggest the occurrence of a large accretionary prism of trench sediments, a possibility subsequently supported by Leg 66 drilling (Moore, Watkins, et al., 1979). (Even so, most of the true oceanic sediment components are apparently consumed.) Vertical movements across the transect have been studied by McMillen and Bachman (in press), as summarized in Figure $11 \mathrm{C}$. During the last $\sim 10 \mathrm{~m}$.y., uplift at the deeper sites $(488,491,492)$ was initially rapid but later slowed, corresponding to the initial rapid uplift at the trench toe followed by slower uplift on the slope. The initial process is a local one due to imbricate thrusting. Later uplift may be more regional in origin, as is also observed at Sites 489 and 493 , drilled on continental crust at the landward end of the transect. We consider this latter movement to represent, at least in part, the vertical tectonics of our model. The curve for the landward sites also shows a very rapid $(1 \mathrm{~km} / \mathrm{m} . \mathrm{y}$.) subsidence in the early Miocene. Perhaps this rapid early subsidence corresponds to the onset of the present phase of subduction (primarily a mantle cooling effect?), roughly synchronous with the age of the trans-Mexican volcanic belt, and later uplift corresponds to the accretion and vertical tectonics inherent in C-type subduction. Whether or not the earliest several million years represent M-type subduction is uncertain.

Lastly, the drilling results for the Middle America Trench off Guatemala (von Huene, Aubouin, et al., 1980) reveal practically no sediment accretion (Fig. 11D), and benthic foraminiferal data indicate dominant subsidence of the trench slope since the early Miocene. These data, although far from definitive, probably attest to the occurrence of M-type subduction for the past $\sim 20$ m.y.

These subduction zone classifications match, by our scheme, the dominantly extensional tectonics we observe in the Mariana fore-arc, that Aubouin, von Huene, et al. (1980) observe off Guatemala, and with the compressional tectonics in the modern sediments of the 
A

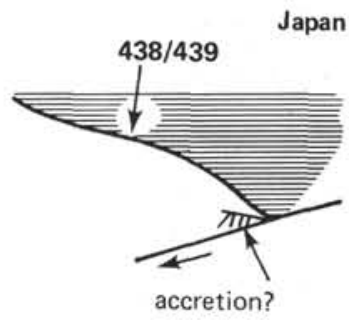

Japan Trench (Legs 56, 57)

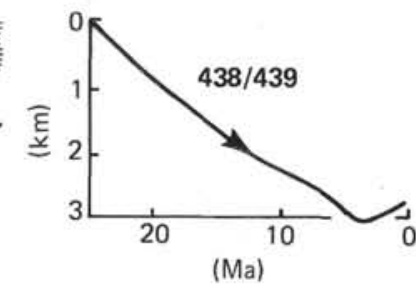

B

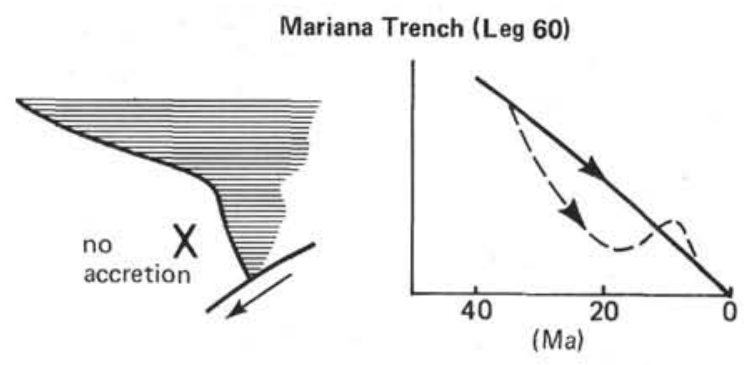

C
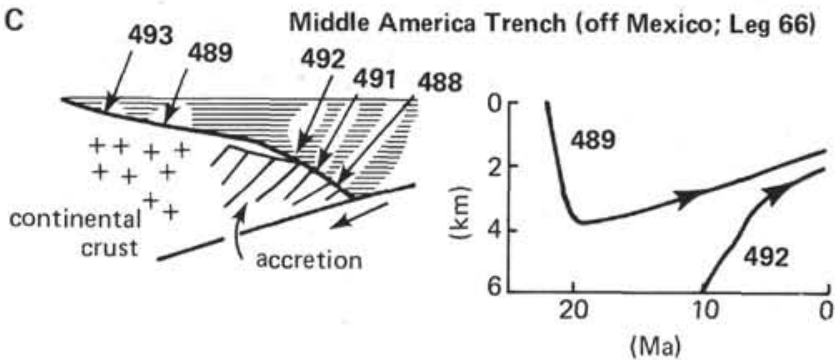

D

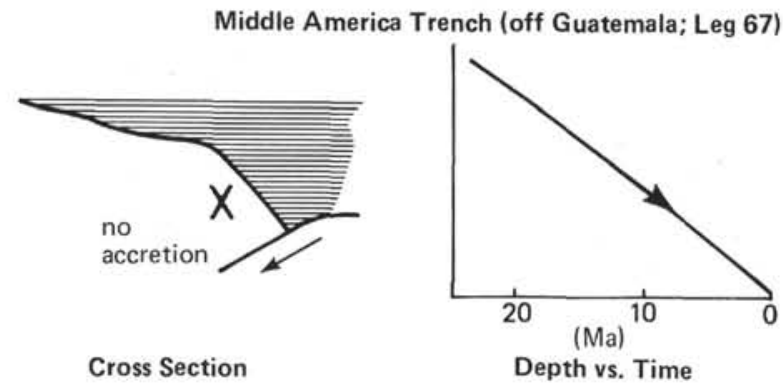

Figure 11. Schematic summary diagram of IPOD active margin drilling showing fore-arc cross sections and subsidence-uplift curves (from von Huene and Uyeda, 1981; McMillen and Bachman, in press).

Japanese fore-arc (Arthur et al,, 1980) and in the Mexican fore-arc (Moore, Watkins, et al., 1979).

An interesting question at this point is why the two relatively closely spaced drilling transects on the Middle America Trench reveal such different tectonic regions. How can Mexico be essentially a C-type subduction zone, whereas only $300 \mathrm{~km}$ away, off Guatemala, subduction seems to be M-type? A solution to this question may be that at the Mexican transect the landward plate is part of the westward-moving North American plate, whereas at the Guatemala transect the overriding lithosphere is the Caribbean plate (Fig. 12). Although the absolute direction of motion of the Caribbean plate is uncertain, its eastward motion relative to the North American plate is undeniable from the nature of its northern transform boundaries and the eastern subduction boundary at the Antilles arc. Thus the landward

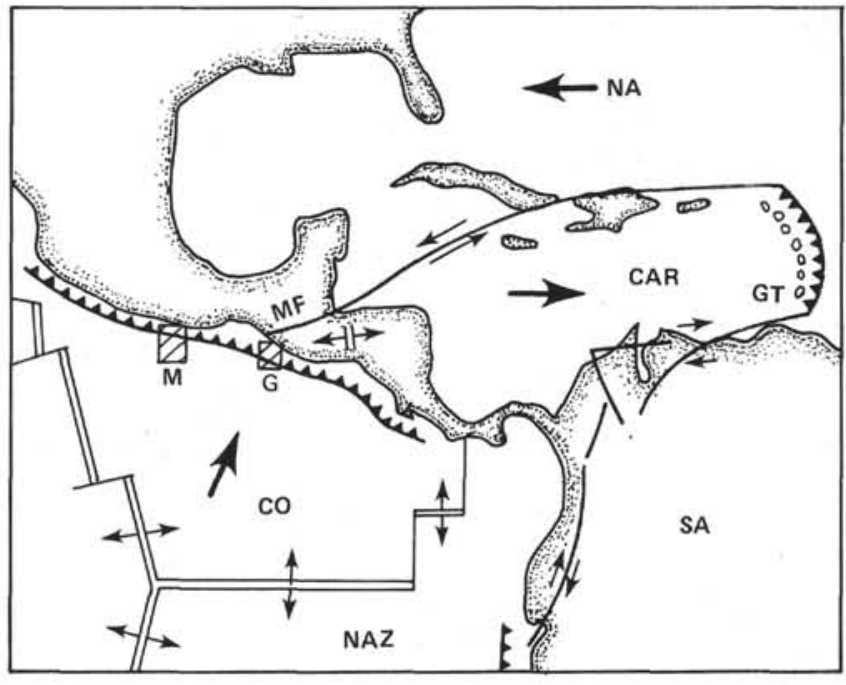

Figure 12. Regional tectonics near the Mexico and Guatemala drilling transects of the Middle America Trench. (NA = North American plate, $\mathrm{SA}=$ South American plate, $\mathrm{CAR}=$ Caribbean plate, $\mathrm{CO}=\mathrm{Cocos}$ plate, $\mathrm{NAZ}=$ Nazca plate, $\mathrm{M}=\mathrm{Leg} 66$ area, $\mathrm{G}=\mathrm{Leg}$ 67 area, $\mathrm{GT}=$ Grenada Trough, $\mathrm{MF}=$ Motagua Fault.)

plate at the Guatemala transect would be far more likely to induce M-type subduction than that at the Mexican transect. In fact, the presence of a diffuse zone of volcanism and graben structure south of the Motagua fault system indicates that the tectonic stress regime in Guatemala is extensional (Plafker, 1976) and therefore produces M-type subduction.

\section{Back-arc Spreading}

As we noted earlier, although back-arc spreading in the Philippine Sea has been episodic, the schemes for determining whether subduction is C-type (no spreading) of M-type (back-arc spreading) are based on tectonic influences that should not change frequently. Although we have identified changes in the direction of plate motion relative to nearly fixed subducting slabs as the cause of alternation between types of subduction, we still do not know why such changes occur as often as the episodic back-arc spreading in the Philippine Sea suggests.

Uyeda, McCabe, and Sugi (1981) suggest that the answer for the Mariana arc system may be that the motion of the Philippine plate is governed by episodic subduction along the western edge of the Philippine Sea (the Mindanao-Philippine-Taiwan-Ryukyu convergence zone). Episodic subduction, including polarity changes, has been inferred from land geology and the regional tectonic setting all along this boundary. The timing of such episodes is, however, far from clearly resolved, and different authors have disparate opinions. Although his is not the most recent investigation, it is interesting to note that Karig (1973) interpreted the cessation of subduction along east Luzon to have occurred in the middle of the Miocene and the beginning of subduction along the Manila Trench at the very end of the Miocene. By this accounting, subduction along east Luzon would end at about the same time that Parece Vela-Shikoku spreading ceased and subduction along the Manila Trench start 
at the same time that spreading began in the Mariana Trough.

Unfortunately, the interpretations of other authors do not provide that good a correlation, and the history of the multiple collisions of arcs and plateaus along the Philippine/Taiwan plate boundary is very poorly defined. We are nevertheless intrigued by the concept that episodic subduction of the western edge of the Philippine plate may be responsible for episodic spreading (and perhaps large-scale rotation) of that plate. If these speculations have merit, then they suggest that the imminent collision of the Benham Plateau, Daito and OkiDaito ridges, and the Amami Plateau may soon block Philippine plate subduction and end the present phase of back-arc opening in the Mariana Trough.

\section{ACKNOWLEDGMENTS}

We wish to thank Frederick K. Duennebier and David Epp for their critical review of this chapter and Jim Natland for his numerous contributions to the synthesis of the results of Leg 60 . Most of all, we are indebted to all the scientists who did the primary shipboard and shore-based studies of the Leg 60 cores which made this synthesis possible.

This work was completed while the first author was on sabbatical leave at the Lamont-Doherty Geological Observatory and was supported by National Science Foundation Grant No. OCE79-1963A1 and the Office of Naval Research Contract N00014-75-C-0209. The chapter is Hawaii Institute of Geophysics Contribution No. 1159.

\section{REFERENCES}

Ambos, E. L., and Hussong, D. M., in press. Crustal structure of the Mariana Trough. J. Geophys. Res.

Anderson, R. N., 1975. Heat flow in the Mariana marginal basin. $J$. Geophys. Res., 80:4043-4048.

Arthur, M. A., von Huene, R., and Adelseck, C. J., Jr., 1980. Sedimentary evolution of the Japan fore-arc region off northern Honshu. In Scientific Party, Init. Repts. DSDP, 56, 57, Pt. 1: Washington (U.S. Govt. Printing Office), 521-568.

Artyushkov, E., in press. Mechanism of formation of active margin. Oceanol. Acta.

Beccaluva, L., Macciotta, G., Savelli, C., et al., 1980. Geochemistry and $\mathrm{K} / \mathrm{Ar}$ ages of volcanics dredged in the Philippine Sea. In Hayes, D. E. (Ed.), The Tectonic and Geologic Evolution of Southeast Asian Seas and Islands: Washington (American Geophysical Union), pp. 247-270.

Ben-Avraham, Z., Bowin, C., and Segawa, J., 1972. An extinct spreading center in the Philippine Sea. Nature, 240:453-455.

Ben-Avraham, Z., and Uyeda, S., in press. Entrapment of oceanic crust as a back-arc basin mode of formation in the western Pacific. In Hilde, T. W. C. (Ed.), Geodynamics of the Western Pacific and Indonesian Region, International Geodynamics AGU/GSA Publication.

Bibee, L. D., Shor, G. G., and Lu, R. S., 1980. Inter-arc spreading in the Mariana Trough. Mar. Geol., 35:183-197.

Boström, R. C., 1971. Westward displacement of the lithosphere. Nature, 234:356-538.

Carlson, R. L., in press. Plate motions, horizontal gradients and the driving mechanisms. In Hilde, T. W. C., and Uyeda, S. (Eds.), Tectonophysics, Special Issue, Convergence and Subduction.

Chase, C., 1978. Extenion behind island arcs and motions relative to hot-spots. J. Geophys. Res., 83:5385-5387.

Dewey, J. L., 1980. Episodicity, sequence and style at convergent plate boundaries. In Strangway, D. (Ed.), The Continental Crust and Its Mineral Resources, Geol. Assoc. Canada, Special Paper 20:553574.

Fischer, A. G., Heezen, B. C., et al., 1971. Init. Repts. DSDP, 6: Washington (U.S. Govt. Printing Office).

Fitch, T. J., 1972. Plate convergence, transcurrent faults, and internal deformation adjacent to southeast Asia and the western Pacific. $J$. Geophys. Res., 77:4432-4460.
Hart, S. T., Glassley, W. E., and Karig, D. E., 1972. Basalts and sea floor spreading behind the Mariana Island arc. Earth Planet. Sci. Lett., 15:12-18.

Hasebe, K., Fujii, N., and Uyeda, S., 1970. Thermal processes under island arcs. Tectonophysics, 10:335-355.

Hilde, T. W. C., Isezaki, N., and Wageman, J. M., 1978. Mesozoic sea floor spreading in the North Pacific. In Sutton, G. H., Manghnani, M. H., Moberly, R., and McAfee, E. U. (Eds.), The Geophysics of the Pacific Ocean Basin and Its Margin: Washington (American Geophysical Union), pp. 205-226.

Hilde, T. W. C., and Sharman, G. F., 1978. Fault structure of the descending plate and its influence of the subduction process. Eos Trans., AGU, 59:1182.

Hilde, T. W. C., Uyeda, S., and Kroenke, L. W., 1977. Evolution of the Western Pacific and its margin. Tectonophysics, 38:145-165.

Hobart, M. A., Anderson, R. N., and Uyeda, S., 1979. Heat transfer in the Mariana Trough. Eos Trans., AGU, 60:383. (Abstract)

Hussong, D. M., Edwards, P. B., Johnson, S. H., et al., 1976. Crustal structure of the Peru-Chile Trench; $8-12^{\circ} \mathrm{S}$ latitude. In Sutton, G. H., Manghnani, M. H., Moberly, R., and McAfee, E. U. (Eds.), The Geophysics of the Pacific Ocean Basin and Its Margin: Washington (American Geophysical Union), pp. 17-85.

Hussong, D. M., and Fryer, P. B., 1980. Tectonic evolution of the marginal basins behind the Mariana Arc. Geol. Soc. Am. Cordilleran Section Mtg., Corvallis, Oregon. (Abstract)

Hussong, D. M., and Sinton, J. B., 1979. Low-level seismicity in the Mariana Trough. Eos Trans., 60(46):877. (Abstract)

Hussong, D. M., and Wipperman, L. K., in press. Vertical movement and tectonic erosion of the continental wall of the Peru Chile Trench near $11^{\circ} 30^{\prime}$ S. In Kulm, L. D., Dymond, J., and Hussong, D. M. (Eds.), Nazca Plate: Crustal Formation and Andean Convergence: Geol. Soc. Am. Mem.

Ida, Y., 1978. Oceanic crust in the dynamics of plate motion and backarc spreading. J. Phys. Earth, 26(Suppl.):355-568.

Jones, G. M., Hilde, T. W. C., Sharman, G. F., et al., 1978. Fault patterms in outer trench walls and their tectonic significance. J. Phys. Earth, 26 (Supplement):S85-S101.

Kanamori, H., 1977. The energy release in great earthquakes. J. Geophys. Res., 80:2981-2987.

Karig, D. E., 1971. Structural history of the Mariana Island arc system. Geol. Soc. Am. Bull., 83:323-344.

1973. Plate convergence between the Philippines and the Ryukyu Islands. Mar. Geol., 14:153-168.

1974. Evolution of arc systems in the Western Pacific. Annu. Rev. Earth Planet. Sci., 2:51-75.

, 1975. Basin genesis in the Philippine Sea. In Karig, D. E., Ingle, J. C., Jr., et al., Init. Repts. DSDP, 31: Washington (U.S. Govt. Printing Office), 857-879.

Karig, D. E., Anderson, R. N., and Bibee, L. D., 1978. Characteristics of back-arc spreading in the Mariana Trough. J. Geophys. Res., 83:1213-1226.

Karig, D. E., Ingle, J. C., Jr., et al., 1975. Init. Repts. DSDP, 31: Washington (U.S. Govt. Printing Office).

Karig, D. E., and Sharman, G. F., 1974. Subduction and accretion in trenches. Geol. Soc. Am. Bull., 86:377-389.

Karig, D. E., Suparka, S., Moore, G. F., et al., 1979. Structure and Cenozoic evolution of the Sunda arc in the central Sumatra region. In Watkins, J. S., Montadert, L., and Dickerson, P. W. (Eds.), Geological and Geophysical Investigation of Continental Margins: AAPG Mem. 29:223-239.

Katsumata, M., and Sykes, L. R., 1969. Seismicity and tectonics of the western Pacific: Izu-Mariana-Caroline and Ryukyu-Taiwan region. J. Geophys. Res., 74:5923-5948.

Keller, G., 1980. Benthic foraminifers and paleobathymetry of the Japan Trench area, Leg 57, Deep Sea Drilling Project. In Scientific Party, Init. Repts. DSDP, 56, 57, Pt. 2: Washington (U.S. Govt. Printing Office), 835-865.

Klein, G. deV., Kobayashi, K., et al., 1980. Init. Repts. DSDP, 58: Washington (U.S. Govt. Printing Office).

Kobayashi, K., and Isezaki, N., 1976. Magnetic anomalies in Japan Sea and Shikoku Basin and their possible tectonic implications. In Sutton, G. H., Manghnani, M. H., Moberly, R., and McAfee, E. U. (Eds.), The Geophysics of the Pacific Ocean Basin and Its Margin: Washington (American Geophysical Union), pp. 235-251. 
Kroenke, L. W., Scott, R. B., et al., 1980. Init. Repts. DSDP, 59: Washington (U.S. Govt. Printing Office).

Kulm, L. D., Schweller, W. J., and Masias, A., 1977. A preliminary analysis of the subduction processes along the Andean coastal margin, $6^{\circ}-45^{\circ} \mathrm{S}$. In Talwani, M., and Pitman, W. C. III (Eds.), Island Arcs, Deep Sea Trenches, and Back-arc Basins, Maurice Ewing Series 1: Washington (American Geophysical Union), 285-321.

Langseth, M. G., von Huene, R., Nasu, N., et al., in press. Subsidence of the Japan Trench forearc region of north Honshu. Proc. 26th Geol. Congress, Paris.

Larson, E. E., Reynolds, R. L., Ozima, M., et al., 1975. Japan-U.S. paleomagnetism project in Micronesia. Paleomagnetism of Miocene volcanic rocks in Guam and the curvature of the southern Mariana Arc. Geol. Soc. Am. Bull., 86:346-350.

LaTraille, S. L., and Hussong, D. M., 1980. Crustal structure across the Mariana Island arc. In Hayes, D. (Ed.), The Tectonic and Geologic Evolution of Southeast Asian Seas and Islands: Washington (American Geophysical Union), pp. 209-222.

Lee, C. S., and Hilde, T. W. C., 1971. Magnetic lineations in the western Philippine Sea. Acta Oceanog. Taiwanica, 1:69-76.

Louden, K. E., 1976. Magnetic anomalies in the West Philippine Basin. In Sutton, G. H., Manghnani, M. H., Moberly, R., and McAfee, E. U. (Eds.), The Geophysics of the Pacific Ocean Basin and Its Margin: Washington (American Geophysical Union), pp. 253-267.

McKenzie, D. E., 1969. Speculations of the consequences and causes of plate motions. Geophy. J. Roy. Astron. Soc., 18:1-32.

McMillen, K. J., and Bachman, S. B., in press. Bathymetric and tectonic evolution of the southern Mexico active margin, DSDP Leg 66. In Moore, J. C., Watkins, J. S., et al., Init. Repts. DSDP, 66: Washington (U.S. Govt. Printing Office).

Meijer, A., 1980. Primitive arc volcanism and a boninite series: Examples from western Pacific island arcs. In Hayes, D. E. (Ed.), The Tectonic and Geologic Evolution of Southeast Asian Seas and Islands: Washington (American Geophysical Union), pp. 271-282.

Minster, J. B., Jordan, T. H., Molnar, P., et al., 1974. Numerical modelling of instantaneous plate tectonics. Geophys. J. Roy. Astron. Soc., 36:541-576.

Molnar, P., and Atwater, T., 1978. Interarc spreading and cordilleran tectonics as alternates related to the age of subducted oceanic lithosphere. Earth Planet. Sci. Lett., 41:330-340.

Moore, J. C., Watkins, J. S., Bachman, S. B., et al., 1979. Middle America Trench off Mexico. Geotimes, 24(No. 9):20-22.

Mrozowski, C., and Hayes, D. E., 1980. A seismic reflection study of faulting in the Mariana fore arc. In Hayes, D. E. (Ed.), The Tectonic and Geologic Evolution of Southeast Asian Seas and Islands: Washington (American Geophysical Union), pp. 223-234.

Nakamura, K., and Uyeda, S., 1980. Stress gradients in arc-back arc regions and plate subduction. J. Geophys. Res., 85:6419-6428.

Niitsuma, N., 1978. Magnetic stratigraphy of the Japanese Neogene and the development of the island arcs of Japan. J. Phys. Earth, 26 (Supplement): 5367-7378.

Plafker, G., 1976. Tectonic aspects of the Guatemala earthquake of 4 Feb., 1946. Science, 193:1201-1208.

Sager, W., 1980. Structure of the Mariana Arc inferred from seismic and gravity data. J. Geophys. Res., 85:5382-5388.
Schweller, W. J., and Kulm, L. D., 1978. Extensional rupture of oceanic crust in the Chile Trench. Mar. Geol., 28:271-291.

Scott, R. B., Kroenke, L. W., Zakariadze, G., et al., 1980. Evolution of the South Philippine Sea: Deep Sea Drilling Project Leg 59 results. In Kroenke, L., Scott, R., et al., Init. Repts. DSDP, 59: Washington (U.S. Govt. Printing Office), 803-815.

Seeley, D., Vail, P. R., and Walton, G. G., 1974. Trench slope model. In Burk, C. A., and Drake, C. L. (Eds.), The Geology of Continental Margins: New York (Springer-Verlag), pp. 249-260.

Seno, T., and Eguchi, T., in press. Seismo-tectonics of Western Pacific Region. In Hilde, T. W. C. (Ed.), Geodynamics of the Western Pacific and Indonesian Regions: International Geodynamics Series AGU/GSA Publication.

Shih, T.-C., 1980. Marine magnetic anomalies from the western Philippine Sea. In Hayes, D. E. (Ed.), The Tectonic and Geologic Evolution of Southeast Asian Seas and Islands: Geophysical Monograph 22: Washington (American Geophysical Union), 49-76.

Sleep, N., and Toksöz, M. N., 1973. Evolution of marginal basins. Nature, 233:548-550.

Stark, J. T., 1964. Petrology of the volcanic rocks of Guam. U.S. Geol. Survey Prof. Paper, 403, C:C1-C32.

Tracey, J. I., Jr., Schlanger, S. O., Stark, J. T., et al., 1964. General geology of Guam. U.S. Geol. Survey Prof. Paper, 403, A: A1-A104.

Uyeda, S., in press. Subduction zones (introduction to comparative subductology). In Hilde, T. W. C. (Ed.), Geodynamics of the Western Pacific and Indonesian Regions: International Geodynamics Series AGU/GSA Publication.

Uyeda, S., and Ben-Avraham, Z., 1972. Origin and development of the Philippine Sea. Nature, 240:176-178.

Uyeda, S., McCabe, R., and Sugi, N., 1981. A hypothetical model for the cause of episodic back-arc spreading in the Philippine Sea. Oji International Seminar on Accretion Tectonics, Sept. 10-16, Tomakomai, Japan, 1981. (Abstract)

Uyeda, S., and Kanamori, H., 1979. Back-arc opening and the mode of subduction. J. Geophys. Res., 84:1049-1061.

Uyeda, S., and Nishiwaki, C., 1980. Stress field, metallogenesis and mode of subduction. In Strangway, D. W. (Ed.), The Continental Crust and Its Mineral Deposits: Geol. Soc. Canada, Special Paper 20, 323-339.

von Huene, R., Aubouin, J., Azéma, J., et al., 1980. Leg 67: The Deep Sea Drilling Project Mid-Trench Trench transect off Guatemala. Geol. Soc. Am. Bull., 91, Part I, 421-432.

von Huene, R., Langseth, M., Nasu, N., et al., 1980. Summary, Japan Trench Transect. In Scientific Party, Init. Repts. DSDP, 56, 57, Pt. 1: Washington (U.S. Govt. Printing Office), 473-488.

von Huene, R., Nasu, N., Arthur, M., et al., 1978. On Leg 57, Japan Trench transected. Geotimes, 23(No. 4):16-21.

Watts, A. B., Weissel, J. K., and Larson, R. L., 1977. Sea-floor spreading in marginal basins of the Western Pacific. Tectonophysics, 37:167-181.

Yonekura, U., in press. Late Quaternary vertical movements in and around the Pacific as deduced from the former shoreline data. In Hilde, T. W. C. (Ed.), Geodynamics of the Western Pacific and Indonesian Regions: International Geodynamics Series AGU/GSA Publication. 